
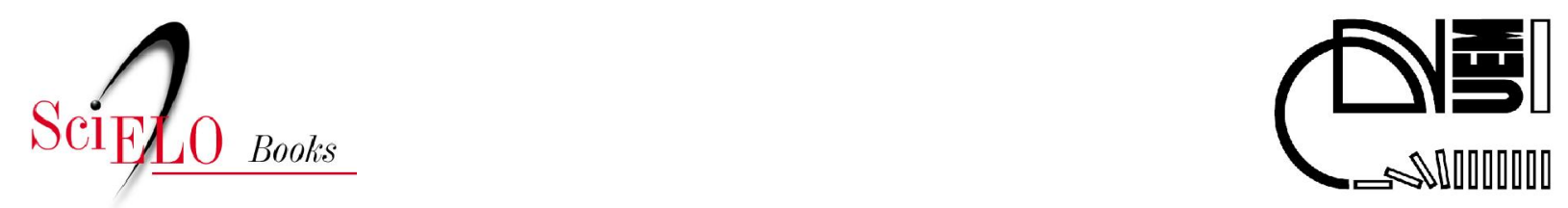

\title{
IV. A expansão do cultivo de café como fator de conformação da paisagem e da estrutura social agrárias do norte do Paraná
}

\author{
Paulo Astor Soethe (org.) \\ Daniel Martineschen (coord.) \\ Caio Heleno da Costa Pereira \\ Dionei Mathias \\ Elisete Antoniuk \\ Fernanda Boarin Boechat \\ Frederico Füllgraf \\ Natasha Pereira da Silva \\ Sibele Paulino \\ Sirlene Nair Neubauer \\ (transl.)
}

\section{SciELO Books / SciELO Livros / SciELO Libros}

SOETHE, PA., org. MARTINESCHEN, D., et al., transl. KOHLHEPP, G. IV. A expansão do cultivo de café como fator de conformação da paisagem e da estrutura social agrárias do norte do Paraná. In: Colonização agrária no Norte do Paraná: processos geoeconômicos e sociogeográficos de desenvolvimento de uma zona subtropical do Brasil sob a influência da plantação de café [online]. Maringá: Eduem, 2014, pp. 81-117. ISBN 978-85-7628-655-4. Available from SciELO Books $<\underline{\text { http://books.scielo.org }>\text {. }}$

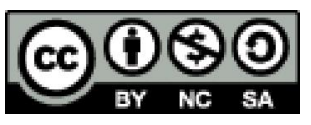

All the contents of this chapter, except where otherwise noted, is licensed under a Creative Commons Attribution-Non Commercial-ShareAlike 3.0 Unported.

Todo o conteúdo deste capítulo, exceto quando houver ressalva, é publicado sob a licença Creative Commons Atribuição Uso Não Comercial - Partilha nos Mesmos Termos 3.0 Não adaptada.

Todo el contenido de este capítulo, excepto donde se indique lo contrario, está bajo licencia de la licencia Creative Commons Reconocimento-NoComercial-CompartirIgual 3.0 Unported. 


\section{A EXPANSÃO DO CULTIVO DE CAFÉ COMO FATOR DE CONFORMAÇÃO DA PAISAGEM E DA ESTRUTURA SOCIAL AGRÁRIAS DO NORTE DO PARANÁ ${ }^{148}$}

\section{DESLOCAMENTOS DAS ÁREAS CENTRAIS DO CULTIVO DO CAFÉ BRASILEIRO}

Rühl (1929) já apontou a livre mobilidade das áreas centrais de cultivo de produtos agrários em países jovens no estágio inicial do desenvolvimento econômico. Esse caso excepcional era o que ocorria no Brasil com relação ao cultivo de café, cujo processo de expansão foi determinado espacialmente pela existência de solos florestais férteis e das vias de transporte que marcavam a distância da costa. O componente cronológico da migração das localizações foi determinado pela velocidade com que se exauria o solo das antigas regiões de cultivo e pelas flutuações do mercado mundial.

No século XX, o ciclo extrativista do cultivo do café assumiu, de maneira cada vez mais intensa, a forma de um permanente movimento evasivo, como escapatória da inevitável intensificação transformadora da gestão do cultivo. Com a colonização das últimas áreas de floresta úmida do sudeste do Brasil, apropriadas para o cultivo de café, esse deslocamento das áreas de cultivo do café no norte do Paraná alcançou sua fase final. Fatores climáticos (geada) e diversos fatores humanos (origem étnica, espírito econômico, sistema agrícola e escolha das plantas cultivadas pela população do sul do Brasil) limitaram de maneira irredutível o alcance da mobilidade espacial das culturas tropicais permanentes em direção ao sul.

A forma tipicamente brasileira de cultivo de café, que geria o sistema de colonato - organizado economicamente pela monocultura de café e em grande medida um sistema empresarial de plantio de autarquia com casa senhorial e numerosas colônias de empregados - , desenvolveu-se no Rio de Janeiro e em São Paulo com base nas experiências do plantio de cana-de açúcar do Nordeste, ${ }^{149}$ moldando-se decididamente pela estrutura social e econômica paulista, sobretudo.

As formas regionais específicas da economia cafeeira do Paraná assumiram com efeito traços essenciais de São Paulo, quanto à disposição e forma de cultivo das plantações e quanto à sua organização de gestão interna de trabalho. No Norte Novo e no Norte Novíssimo, entretanto, elas se diferenciaram significativamente do tipo paulista de 'civilização do café' quanto à relação socioeconômica ${ }^{150}$. Enquanto o Norte Velho do nordeste do Paraná é um 'clássico' desdobramento da economia cafeeira tradicional paulista, as inovações vindas da fronteira oeste do café em São Paulo sob a influência da crise econômica mundial, passaram ao largo dessa região paranaense e prosseguiram com seu processo de expansão mais adiante, na fronteira oeste do rio Tibagi ${ }^{151}$. Quanto a essas inovações, deve-se incluir a implantação - revolucionária para o Brasil - de pequenas e médias propriedades no cultivo de café, o melhor cultivo das sementes e a escolha de variedades, a maior densidade da lavoura (GUIMARÃES, 1953, p. 46) e a tendência mais forte à diversificação da área de plantio, assim como o desenvolvimento de culturas intermediárias e a mobilidade social junto à fronteira.

148 Tradução de Sibele Paulino e Fernanda Boarin Boechat.

149 As primeiras plantações de café no Vale do Paraíba foram estabelecidas pelos baianos que traziam seus escravos das regiões de plantação de cana-de acúcar para o Rio e São Paulo e lá adquiriam terras.

150 Conceito segundo Araujo (1956, p. 115).

151 Sobre o problema da difusão de processos de inovação, cf. Hägerstrand (1967, tradução de 1953) e Borcherdt (1961). 


\section{a) Modelos temporais e espaciais de propagação do cultivo de café em São Paulo}

Para compreender os deslocamentos do cultivo brasileiro de café e o seu significado para o Paraná, primeiramente devem ser elucidadas as fases decisivas do processo de expansão em São Paulo.

Na região nordeste em torno de Ribeirão Preto, uma das poucas áreas de terra roxa do estado de São Paulo, desenvolveram-se, no último terço do século XIX, as enormes plantações de café, que caracterizaram o estado durante muito tempo. Começando pelo estado do Rio de Janeiro, duas fases do 'roteiro do café' (MILLIET, 1941) no Vale do Paraíba (1830-1885) e na região em torno de Campinas (1850-1900) haviam precedido a abertura daquela região e deixaram para trás solos exauridos e prejuízos da erosão, depois de um tempo relativamente curto de prosperidade (MONBEIG, 1952); CAMARGO; TELLES, 1953; FRANÇA, 1956; ARAÚJO FILHO, 1956; PRADO JR. 1962; TAUNAY, 1961; FURTADO, 1968). A abertura de vias de transporte seguiu-se à migração do cultivo de café dos arredores dos centros populacionais próximos à costa - Rio de Janeiro e São Paulo - para o sertão inexplorado do planalto, no interior. Em 1883, a linha férrea de Mogiana chegou a Ribeirão Preto e possibilitou o transporte da colheita de café e a entrada de mão de obra, o que sempre faltava na região pioneira. Depois da abolição da escravatura em 1888, imigrantes europeus tornaram-se a força de trabalho, sobretudo os italianos.

Latifundiários como Almeida Prado, Silva Prado, Toledo Piza, Queiroz Telles ou Alves de Lima tinham domínio sobre extensas plantações de café. Eles e parte considerável dos membros de seus clãs conquistaram influência política e econômica significativa ao atuarem como políticos (secretários de Estado de Economia, prefeitos de São Paulo, entre outros), banqueiros, diretores de companhias de estrada de ferro e de empresas comerciais. Além disso, controlavam a política estatal com a economia cafeeira. Diversos proprietários rurais de muitas posses vindos de Minas Gerais, que em parte tinham emigrado de São Paulo para lá durante a febre do ouro, retornaram a São Paulo, e faziam parte do grupo dos primeiros grandes proprietários de plantações de café no nordeste do estado, constituindo a nova elite do Brasil (MONBEIG, 1952, p. 121ss.; DAMBAUGH, 1959, p. 5).

Mas não eram somente os tradicionais paulistanos fazendeiros do café - cujos filhos em parte já deixavam a direção dos negócios nas mãos de administradores e se dedicavam a operações financeiras em São Paulo - que tiveram a possibilidade de constituir fortuna com o cultivo desse grão. O primeiro grande boom do café possibilitou também a imigrantes europeus uma ascensão econômica inesperada na região pioneira, a exemplo de um Franz Schmitt ou Geremia Lunardelli, que foram elevados a 'reis do café' na virada do século e possuíam cada um mais de 10 milhões de árvores!

Depois da proibição oficial da escravatura em 1888 e da emigração dos ex-escravos para as cidades grandes, o suprimento das plantações de café com mão de obra representou um dos maiores problemas de São Paulo. Com a imigração em massa de europeus, iniciou-se uma nova fase do desenvolvimento econômico e populacional do estado.

Se entre 1875 e 1886 chegaram a São Paulo algo mais de 42 mil imigrantes, entre 1887 e 1900 uma onda de imigração inundou o estado com 910 mil pessoas, que em 1886 já contava com 1,22 milhões de habitantes (PETRONE, 1956, p. 41) ${ }^{152}$. Cerca da metade desses imigrantes veio da Itália e um terço da Espanha. Os imigrantes sul-europeus foram levados em sua maior parte diretamente às plantações, onde eram empregados como 'colonos' e, mais tarde, também como 'parceiros'. Nas primeiras duas décadas do século XX, outros 890 mil imigrantes seguiram para São Paulo ${ }^{153}$.

Em São Paulo, a classe trabalhadora das plantações de café compunha-se em sua maioria de imigrantes europeus, sobretudo italianos. Os colonos italianos destacavam-se por meio da rápida adaptação e aprendizado no tratamento de problemas com relação aos cuidados do café, e percebiam, com isso, a chance de se tornarem parceiros ou arrendatários onde quer que fosse. Muitos dos descendentes desses trabalhadores rurais foram recrutados para o Paraná numa consequente migração interna da metade do século XX, o que trouxe consigo, além da mobilidade espacial, uma mobilidade social significativa (ver Cap. IV, 3).

152 No ano de 1900, 23,2\% da população paulistana eram estrangeiros; em comparação ao mesmo período e à mesma situação, nos Estados Unidos a parcela de estrangeiros era de 13,4\%.

153 No Paraná, no período de 1889 a 1934, houve uma imigração oficial de apenas 82 mil pessoas, se comparado aos 1,8 milhões de imigrantes em São Paulo entre os anos 1887 e 1920 ! 
O deslocamento do cultivo de café dentro de São Paulo realizou-se no interior das famílias de fazendeiros como sucessão de gerações na região, sob o espírito bandeirante inalterado de seus membros. Se o avô tivesse uma plantação na área de Campinas, os filhos se radicariam na região da Alta Mogiana próximo a Ribeirão Preto e, por sua vez, investiriam para os filhos em plantações de café na região da Alta Paulista (MONBEIG, 1952, p. 110). Até 1920 o cultivo de café se expandira, em São Paulo, para o centro do estado na zona de arenito cretáceo do Grupo Bauru e para os espigões entre os afluentes do Rio Paraná154 (Mapa 19). Até a grande crise do café atrelada à crise econômica mundial, a década seguinte levou o avanço mais distante rumo a oeste ao longo da linha divisora de águas.

A construção da grande linha férrea seguiu-se imediatamente à colonização do café. Por trás disso, a colonização se sucedeu em um típico modelo de frontier (JAMES, 1938, p. 356) que, em São Paulo, não foi conduzido na forma de integração entre transporte e colonização (MONBEIG, 1937, p. 349). O cultivo de café na região dos espigões pôde conformar-se com os solos do arenito Bauru, que eram de qualidade inferior e além disso apresentavam os preços de terra mais altos ao longo da linha férrea. Por outro lado, com frequência havia rochas vulcânicas expostas nos vales e, com isso, confirmava-se a existência de solos de terra roxa ('misturada'). No entanto, os solos dos vales, sobretudo no sudoeste por causa de sua altitude, não eram propícios ao cultivo de café e à colonização, porque normalmente havia o perigo da geada no inverno e, no verão, eclodiam constantemente epidemias de malária. O gráfico de distribuição da população urbana e rual caracteriza esse movimento de expansão (Mapa 16).

As regiões de divisoras de águas e com elas as zonas de cultivo de café de São Paulo ficaram conhecidas pelos nomes das companhias da estrada de ferro: de norte a sul, a 'Alta Araraquarense' (entre o rio Turvo e o rio São José dos Dourados); a 'Douradense' (entre o rio São José dos Dourados e o Tietê); 'Noroeste' (Tietê-Aguapeí); 'Alta Paulista' (Aguapeí-Peixe) e 'Alta Sorocabana' (Peixe-Paranapanema) (GUTERSOHN, 1940; MILLIET, 1941; FRANÇA, 1956; Mapa 19). À exceção da linha 'Noroeste', que fazia conexão com o Mato Grosso do Sul, as linhas restantes terminavam no rio Paraná.

Desde 1928 a crise do café não pôde impedir a expansão de novas plantações no sentido oeste. Ela causou, no entanto, uma tranformação no caráter do frontier: não mais os grandes fazendeiros eram a força motriz da expansão do café, mas sim os sitiantes, um número considerável de pequenos proprietários de terra e invasores [squatter]. Juntamente com os imigrantes europeus e japoneses ${ }^{155} \mathrm{e}$ colonos de plantações de café, também inúmeros nordestinos (sobretudo da Bahia e de Pernambuco) migraram para São Paulo, depois do forte aumento da migração interna desde 1919, e passaram a almejar a aquisição de propriedades (JAMES, 1938; KELLER, 1954).

Além disso, a ampliação do frontier para novas regiões de floresta foi acompanhada - em esquema tradicional - pela diminuição de produção em antigas regiões de cultivo, pelo abandono de plantações improdutivas, pela mudança para criação de gado e pelo despovoamento (JAMES, 1932, p. 244).

James (1932) supunha, em vista das relações de solo e de clima das zonas de cultivo jovens, "uma diminuição da margem do café", consolidação do cultivo do café e uma concentração para trás das faixas de terra roxa da região central de São Paulo. Também Platt (1935, (p. 239) acreditava no fim da expansão do cultivo do café: "Tendo em vista a depressão mundial de maneira geral e o fracasso da política do café no Brasil em particular, a região do café pode preservar a sua forma atual por muitos anos, suas lacunas podem permanecer não preenchidas e seu frontier inalterado. Marília pode envelhecer e ainda se manter como uma cidade de frontier"156.

Enquanto grandes capitais de proprietários de plantações de café eram aplicados na indústria depois da distribuição e da venda das terras, e proporcionavam a São Paulo um impulso industrial significativo, o algodão se transformou no novo produto agrícola comercial [cash-crop] das zonas pioneiras. Um fluxo intenso de japoneses se iniciou. ${ }^{157} \mathrm{Na}$ verdade, apenas 1,8\% dos japoneses possuíam suas próprias terras,

154 O Mapa 19 mostra a média de produção de café por ha em diferentes fases. Para poder avaliar o avanço do cultivo de café apropriadamente, deve-se considerar que os cafeeiros ainda não produtivos com menos de 4 ou 5 anos da zona pioneira não foram computados aqui cartograficamente. Essas plantações jovens estendiam-se por toda região entre o nível de produção mais baixo (cafeeiros entre 4 e 6 anos antes da produtividade máxima) até a frente pioneira.

155 Entre os 584.000 imigrantes estrangeiros que vieram com destino a São Paulo, no período entre 1921-1934, os japoneses predominavam com $23 \%$ sobre os portugueses (20\%) e os italianos (13\%) (PETRONE, 1956, p. 43).

156 No original, em inglês: "In view of world-wide depression in general and the failure of Brazilian coffee policy in particular, the coffee region may retain its present form for many years to come, its gaps unfilled, its frontier unchanged. Marilia may grow old and still remain a frontier town".

157 No ano de 1934, os japoneses perfaziam 18\% da população do estado de São Paulo. 
entretanto eles cultivavam $46 \%$ do algodão em São Paulo e produziam quase 30\% da produção agrária do estado. De 1932 até 1935, o crescimento excepcional do cultivo do algodão - de 72.000 ha para 653.000 ha - junto ao crescimento de trabalhadores rurais - de 30.000 para 250.000 - , resultou, em 1935 e 1936, numa forte emigração populacional da região do café, de modo que $20 \%$ das plantações não puderam ser cultivadas por conta da escassez de trabalhadores ${ }^{158}$. No fim dos anos 30 , porém, houve novamente uma recuperação da situação na economia do café.

Por volta de 1940, o ponto forte da produção brasileira de café encontrava-se na região de Bauru e Marília e, já com uma participação relativamente significativa, no Norte Velho do Paraná. Enquanto em São Paulo a expansão do cultivo de café em 1950 revelava um afastamento significativo do modelo de ampliação indiscriminada de área em direção ao de seleção regional mais intensa de áreas de cultivo ecologicamente favoráveis, ${ }^{159}$ o frontier do café no Norte do Paraná avançava de modo ininterrupto para oeste e sudoeste, ainda em um fronte amplo (Mapa 19).

\section{b) O avanço do frontier do café no Norte do Paraná}

Ao contrário de muitas outras regiões do interior do Brasil e da região do planalto mesozóico central e sul do Paraná, onde ocorreu o processo de colonização não em fronte fechado mas de modo pontual e linear em avanços isolados uns dos outros, surgiu no norte do Paraná, a oeste do rio Tibagi, uma autêntica 'frente pioneira', ${ }^{160}$ que se assemelha à "unidade de movimento do frontier" [unity of frontier movement] de Turner $(1920)^{161}$. Os pioneiros não se infiltravam em interstícios despovoados às costas de 'frontiers vazios' [hollow frontier], ${ }^{162}$ mas se apoderavam efetivamente de terras florestais e de modo permanente.

Na América Latina, há poucos exemplos desse movimento de expansão de atividades de pequenos agricultores com tendências à intensificação do uso da terra. Seriam eles o planalto de Costa Rica, Antioquia, na Colômbia, a região norte do Chile central e o sul do Brasil ${ }^{163}$. Enquanto no cultivo de café da Costa Rica e da Colômbia a pequena propriedade se converteu em um elemento característico, o Norte do Paraná constitui um caso especial tanto para o movimento de frontier brasileiro de maneira geral quanto para o avanço do frontier do café de modo específico. "Essa é a nova frente, uma frente

158 Segundo Immigration and settlement in Brazil, Argentina and Uruguay, 1937, p. 235; e James (1938, p. 357-359); sobre isso também Matos (1954).

159 Apenas quase 15\% das plantações de café em São Paulo estavam em áreas de terra roxa, enquanto 64\% dos cafeeiros tinham o seu lugar nos solos arenosos da região de Bauru (United Nations, 1960, p. 22).

160 Cf. sobre isso as explicações de C. Bernardes (1953, p. 374), que, no entanto, baseiam-se apenas na expansão até cerca de 1950 e ainda não consideram a investida principal sobre o rio Ivaí para o oeste. Do mesmo modo, Lehmann (1958, p. 71).

161 A teoria de frontier de Turner, do ano de 1893, desenvolvida para os EUA, desperta até hoje uma discussão de suas ideias na literatura histórica, geográfica e sociológica. Entre os trabalhos mais recentes, deve-se mencionar Beck (1955), Wyman e Kroeber (ed., 1957), Gulley (1959), Hofstadter e Lipset (ed., 1968), entre outros. Sobre o problema do frontier na América hispânica, ver Zavala (1957).

O uso do conceito de frontier de Turner compreende quatro significados complementares: 1) 'linha de expansão' [frontier line] como linha de densidade populacional entre áreas com menos ou mais que 2 pessoas por milha quadrada; 2) 'zona de população esparsa' [zone of sparse population]; 3) 'margem inóspita' [wilderness margin] e 4) 'fronteira com uma organização econômica específica, vida pioneira' [border with a specific economic organization, pioneer life] (GULLEY, 1959, p. 65 e BECK, 1955, p. 59ss.).

Cf. em contrapartida Bowman (1931, p. 53): "Nenhuma área pioneira é um cinturão amplo e ininterrupto. Pelo contrário, ela é uma série de fragmentos esparsos e faixas dispostas de maneira vaga na forma de um cinturão, para além da franja do assentamento atual." [No pioneer area is a broad unbroken belt. It is, rather, a series of scattered patches and strips loosely disposed in beltlike form beyond the fringe of present settlement].

O significado do avanço do frontier para os EUA (PFEIFER, 1935) se dá, para Turner, a partir de um afastamento permanente da influência europeia e de um aumento consequente da independência americana. No frontier móvel do café no Brasil, permanecia, no entanto, uma duradoura dependência, no sentido quantitativo e qualitativo, da atitude consumista do alémmar devido à orientação do mercado mundial dos produtos agrícolas de mercado [cash crops].

162 Sobre o problema do 'frontier vazio' [hollow frontier] como exploração especulativa do interior, em grande medida típico para o Brasil, sob a forma de uma fase de transição do uso agrícola com degradação imediata por causa da devastação total da floresta, esgotamento do solo e mobilidade elevada da população do campo, ver James (1938, p. 361-62).

163 James (1941, p. 183) divide essas áreas em "quatro frontiers que não são vazias" [four frontiers which are not hollow]. (Para Costa Rica, cf. SANDNER, 1961; para Antioquia, PARSONS, 1968). O desenvolvimento no planalto de Antioquia é o que mais de aproxima da concepção de Turner sobre o frontier (HOFSTADTER e LIPSET, 1968, p. 155). - James entende como sendo sul do Brasil os três estados do sul de maneira geral, e não faz qualquer referência direta ao Norte do Paraná, que naquela época estava no começo do seu desenvolvimento. 
diferente e a última frente" [This is the new frontier, a different frontier and the last frontier] (DAMBAUGH, 1959, p. 22). ${ }^{164}$

A colonização do Norte Novo e Novíssimo do Paraná, que se deu no âmbito da colonização privada dirigida, não era dependente nem da autoridade de proprietários de plantações influentes, nem de coronéis ${ }^{165}$. A mudança da estrutura de propriedade tinha sido anunciada em São Paulo com a crise econômica mundial e impôs-se com o surgimento de novos produtos agrícolas de mercado, como o algodão, e de uma nova camada social de pequenos proprietários rurais. Pequenos e médios estabelecimentos agrícolas tornaram-se os tipos dominantes de atividades da zona pioneira paranaense, depois da economia cafeeira se revigorar.

Esse tipo de zonas pioneiras surgem "[...] quando de repente a expansão da agricultura se acelera por algum motivo, quando uma espécie de febre atinge a população do entorno mais próximo e mais distante, e se inicia o influxo de uma corrente humana intensa. Em outras palavras: quando a agricultura e a colonização provocam o que os americanos [...] chamam de boom ou rush. Então o preço das terras vai às alturas, as florestas são derrubadas, casas e ruas são construídas, povoados e cidades surgem da noite para o dia e um espírito arrojado e otimista acomete toda a população" (WAIBEL, 1955b, p. 393, trad. do autor).

O norte do Paraná se tornou o novo Eldorado do Brasil, e a produção cafeeira orientada pelo mercado mundial fez surgir uma das poucas zonas pioneiras clássicas do país, o que se compara ao desenvolvimento norteamericano no Centro-Oeste ${ }^{166}$. Se somente a venda de terras da CTNP entre 1945 e 1950 havia superado em quase 500.000 ha a venda total de terras dessa sociedade desde 1930, as compras de terra se multiplicaram sobretudo por causa do avanço de área da colonização do café na região do Norte Novíssimo, para norte e para sul do rio Ivaí.

A colonização agrária resultou de uma forte migração interna, que avançou de São Paulo ou a usou como estação intermediária para o Norte do Paraná. Antes de cada período de arroteamento (maio-agosto) e de plantio (setembro-outubro), filas extensas de caminhões carregados esperavam nos cruzamentos com rios em São Paulo para realizar a travessia com ferryboats, o que interrompia a viagem para o oeste. Embora a imigração também se desse por meio do trem, o avanço do frontier para o oeste de Maringá foi caracterizado somente pelo transporte de caminhão, cujo emprego causou a nova orientação geográfica e de tráfego da zona pioneira. Postos de gasolina e oficinas mecânicas foram criados e linhas de ônibus circulavam até as novas colônias na fronteira de área desmatada.

O movimento de massa de pioneiros, imprescindível para o frontier nos EUA por causa do perigo da presença indígena, explica-se no Norte do Paraná tanto a partir do tipo de produção agrícola de mercado do café - que, enquanto arboricultura, necessita de quatro anos até a primeira colheita e somente a partir do sétimo ano produz colheitas ideais - quanto também a partir das áreas limitadas da região. Os colonos tentavam adquirir o mais rápido possível terras baratas ${ }^{167}$

164 O avanço em direção ao Rio Paraná representava o fim dos deslocamentos do cultivo do café.

$165 \mathrm{O}$ coronel, em geral um comerciante rico com grande influência local e regional, exercia uma autoridade política peculiar no Brasil rural. "Pequeno tirano local, que invalidava qualquer sistema político democrático, o coronel ainda era capaz de realizar obras úteis" [Petit tyran local, viciant tout système politique démocratique, ce coronel était donc pourtant capable de faire oeuvre utile] (MONBEIG, 1952, p. 125). Baseado na estrutura social tradicional do campo no Brasil, o coronelismo significa uma coexistência de resquícios de poder privado do proprietário e a representação local do regime político. O aparecimento do coronelismo foi favorecido pela grande distância dos centros urbanos e o isolamento das localidades rurais, e alcançou o seu ápice em São Paulo, entre 1890 e 1920/30 (sobre isso, ver TORRES, 1965).

166 Waibel (1955b) evidenciou as diferenças das zonas pioneiras americanas e da maioria das brasileiras nos pressupostos naturais, quanto ao andamento da apropriação de terra e da colonização, assim como quanto às relações de mercado e de tráfego, mas também ressaltou a igualdade incipiente do sistema agrícola e do espírito especulativo dos colonos. Ao contrário do desenvolvimento nos EUA, o cultivo pelo sistema de coivara e da rotação de terras constituíram, em várias partes do Brasil, não um fenômeno passageiro, mas sim um estado permanente. - O mercado interno ausente e a carência de conexões de transporte eficazes impediam uma colonização em massa no interior do Brasil. São Paulo e o Norte do Paraná, com sua orientação de exportação baseada no comércio mundial de café, representavam as grandes exceções entre as zonas pioneiras do Brasil.

167 Bowman $(1931$, p. 6) descreve essa situação em suas observações gerais sobre "a margem pioneira": "Boa parte da vantagem do pioneirismo reside em chegar lá antes, pois a essência da coisa consiste em conseguir terra boa por baixo preço" [A large part of the advantage of pioneering lies in getting there first, because the essence of the thing is to get good land cheap]. Na área fora da colonização dirigida do Norte do Paraná, o slogan dos invasores "não basta estar no encalço do agrimensor; deixe que ele esteja no seu encalço" [it is not enough to be on the heels of the surveyor; let him be on your heels] (BOWMAN, 1931, p. 6) tinha o mesmo significado do dos colonos fronteiriços do frontier americano (PFEIFER, 1935, p. 155). 
e começar imediatamente o cultivo de café, antes que se iniciasse a extensa produção massiva e com isso novamente a queda dos preços. O fato de estar adiantado em uma colheita em relação ao vizinho significava, com frequência, a base para a construção de um patrimônio. Uma outra vantagem sucedia quando no ano seguinte, depois de estragos de geada, a colheita anterior podia ser mais valorizada, graças à especulação.

Enquanto o frontier ao norte do Ivaí já tinha alcançado o Paraná na primeira metade dos anos 1950, a frente pioneira avançou ao sul do Ivaí somente em 1960 até a fronteira oeste do país (Foto 1). Permaneceram inabitadas apenas a foz do Ivaí e do Piquiri, assim como a região de floresta situada na parte baixa da Bacia do Paraná, ente as regiões de confluência de ambos os rios (Mapa 11) ${ }^{168}$.

A velocidade e intensidade do avanço da frente pioneira se reflete claramente na fundação ou no surgimento dos municípios atuais do Norte do Paraná (Figura 2). A crescente recolonização das áreas de floresta tropical a oeste do Tibagi, na primeira fase até o fim da Segunda Guerra Mundial, corresponde ao número relativamente pequeno de fundações de colônias até 1944. Na segunda metade dos anos 1940, observa-se um forte aumento de atividade fundadora estatal e privada. O boom do café, que imperava desde 1950, manifestava-se em um único acúmulo de fundação de colônias. Na área da Cia. Melhoramentos Norte do Paraná, surgiram 22 novos lugares num período de 5 anos que se tornaram definitivamente sedes de municípios autônomos (Mapa 14 e Figura 2). Enquanto na antiga área da CMNP ainda foram fundados, depois de 1955, apenas alguns 'patrimônios' tanto por parte da sociedade de colonização quanto por iniciativa privada ${ }^{169}$ - os quais são, em parte, 20 anos mais tarde, sedes distritais - , a fundação de novos núcleos reginais só teve fim em 1960, e mesmo fora da região da CMNP, alcançando o rio Paraná.

No período entre 1947 e 1955, as fundações das cidades da CMNP foram projetadas em maior extensão, levando em conta o crescimento econômico do Norte do Paraná de maneira geral. Desse modo, Maringá, Cianorte e Umuarama excederam de longe a já existente Londrina, em vista da área reservada para a cidade (Tabela 5). O tipo de colônia planejada de frontier, predominante no Norte Novo e Novíssimo, era uma forma absolutamente nova de colonização na zona pioneira que havia se imposto em São Paulo pela primeira vez nos anos $1930^{170}$.

O espírito pioneiro do Norte do Paraná no momento da fundação dos pontos centrais de colônias encontra expressão também nas denominações dos lugares privados e estatais que foram fundados (Mapa 22). Ao lado de inúmeros nomes tupi-guarani, ${ }^{171}$ criações modernas de grupos de visão nacionalista ${ }^{172}$, nomes de santos difundidos em todo Brasil ${ }^{173}$ e nomes de fundadores de colônias ou políticos, ${ }^{174}$ predominam as designações de otimismo e espírito pioneiro ${ }^{175}$.

168 Após o fim da guerra, suspenderam-se novamente a desvinculação das regiões fronteiriças do oeste de Santa Catarina e Paraná, ocorrida em 1943 por razões estratégicas, e a formação do território de Iguaçu, com quase 66.000 km², estendendo-se do rio Ivaí, ao norte, até o rio Uruguai, ao sul.

169 Até o o começo de 1970, havia sido fundado um total de 62 localidades pela CMNP, das quais 35 eram sedes de municípios e 27 localidades distritais. As 50 fundações privadas nas terras da CMNP dividem-se em 14 localidades municipais, 24 localidades distritais e 12 'patrimônios'.

170 Cf. Monbeig (1937) e Gutersohn (1940). Com frequência a planta ortogonal do mapa da cidade foi acrescida de ruas diagonais por razões técnicas ligadas ao trânsito. Por razões psicológicas, deu-se valor especial ao crescimento orgânico que ia do centro para a periferia, à construção de casas de pedra (agraciadas com prêmios) e à conformação da praça, pois a cota de atratividade migratória dependia da aparência externa.

171 Iguaraçu, Apucarana, Ivaiporã, Icaraima, Mandaguari etc.

172 Por razões nacionalistas, alguns nomes foram modificados: Nova Dantzig para Cambé; Lovat (fundador da Paraná Plantations) para Mandaguari; Roland para Caviúna, que, depois da guerra, voltou no entanto a se chamar Rolândia.

173 São Jorge, Santa Inês, São João do Ivai, Santo Antonio etc.

174 Presidente Castelo Branco, Engenheiro Beltrão, Doutor Camargo, Janiópolis.

175 Grandeza, beleza, alegria, esperança, sucessos: p. ex. Bela Vista do Paraíso do Norte, Terra Rica, Pérola, Bom Sucesso, Alvorada, Diamante do Norte, Nova Esperança, Jardim Alegre, Fênix, Florestópolis entre outros. 
Figura 2: Fundação dos principais centros municipais atuais

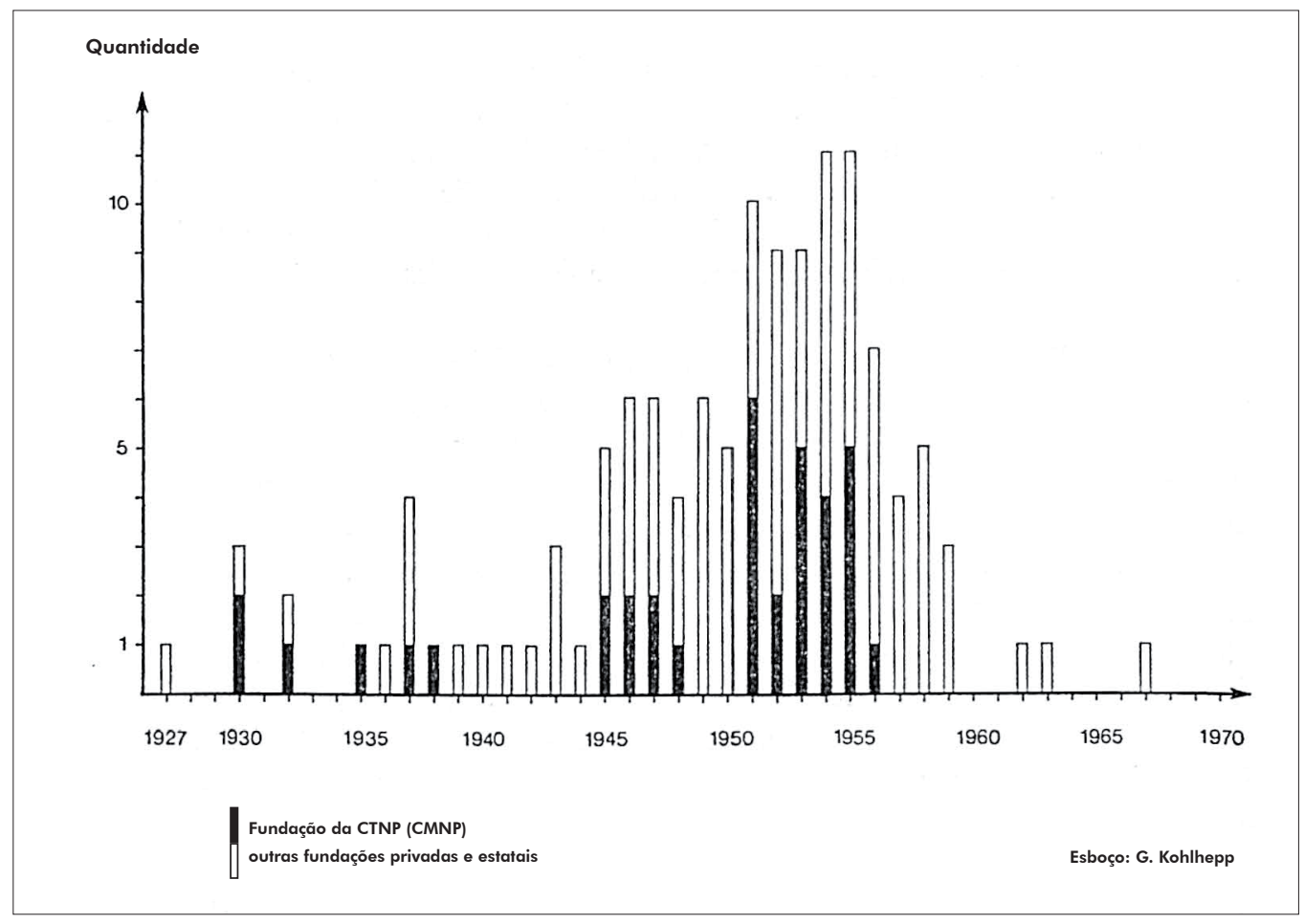

Fontes: Arquivos da CTNP, documentos do DGTC; IBGE, 1959, vol. 31, Paraná.

O processo de derrubada transformou grande parte do Norte Novíssimo ao longo de poucos anos. Como mostra o exemplo da região em torno de Cianorte, lá ocorria também o desmatamento em geral ao longo de clareiras nas divisoras de águas (Mapa 20), onde já havia sido planejado um extenso caminho principal para a futura construção da estrada de ferro. No período de uma década, a floresta tropical praticamente desapareceu, à exceção de poucos vestígios nos vales do rio e de um cinturão verde em torno do centro urbano de Cianorte (Mapa 21). Uma densa rede de ruas e de caminhos percorre a jovem paisagem cultivada, cujas áreas preenchidas e desmatadas - porém ainda com tocos de árvore apodrecendo - são tomadas de cafeeiros - à exceção do sopé do vale e das encostas mais baixas.

O cultivo de café estabeleceu novas medidas econômicas no Norte do Paraná, depois que as consequências da crise do café e a situação de transição durante a Segunda Guerra Mundial foram superadas. O aumento abrupto dos preços do café (ver Cap. V), no fim dos anos 1940 e no começo dos 1950, fez surgir um boom do cultivo do café no Norte do Paraná, que, fundado na pequena e média propriedade, superava todos os recordes de São Paulo até então.

A reserva de cafeeiros, que havia aumentado para 233 milhões até 1950 (1942: 61 milhões), sendo $55 \%$ no Norte Velho, alcançou no Norte do Paraná:

$\begin{array}{rr}\text { em } 1953 & 695 \text { milhões } \\ \text { em 1958 } & 1.141 \text { milhões } \\ \text { em 1961 } & 1.281 \text { milhões }\end{array}$

(ver Figura 3)

Destes números, $85 \%$ ficavam no Norte Novo e Novíssimo. A área de cultivo compreendia mais de 1,5 milhões de hectares em 1958.

Em 1950/51, o Paraná já tinha superado em número de cafeeiros o estado do Espírito Santo, que até então estava em $3^{\circ}$ lugar no Brasil; em 1952/53, superou também Minas Gerais; em 1961, alcançou e 
ultrapassou o desde então dominante estado no cultivo de café, São Paulo, cujas reservas mais velhas e menos produtivas tinham sido radicalmente reduzidas desde $1960^{176}$.

O aumento da produção do café no Paraná ocorreu não apenas com a usual fase de retardamento de 4 anos até o amadurecimento da produção das árvores, mas por causa de duas geadas de intensidade moderada, em 1953 e 1955, com um adiamento adicional de 2 a até 3 anos. Depois das colheitas fracas por causa da geada nos anos de 1954 e 1956 - que fizeram com que o Paraná fosse mais uma vez superado e alcançado pela produção em Minas Gerais e Espírito Santo - , a primeira grande colheita de 1958 rendeu 8,6 milhões de sacas de $60 \mathrm{~kg}$ e foi excedida, já em 1959, por um recorde de 20,7 milhões de sacas de $60 \mathrm{~kg}$ (Figura 3). Com isso, o Norte do Paraná também ultrapassou São Paulo e tornou-se uma região de cultivo de liderança no Brasil, sendo que a participação na produção total de café no Brasil cresceu 50\% até 1961.

Depois que as plantações de café das zonas pioneiras do Norte do Paraná entraram em plena produção, a situação da economia cafeeira brasileira mudou totalmente dentro de uma década. O Norte Novo e Novíssimo do Paraná ocuparam uma posição dominante (Figura 2). Os férteis solos de terra roxa das florestas tropicais representavam os principais atrativos. O fluxo da população pioneira que procurava por terras desembocou, no entanto, mais adiante para o noroeste, na região dos solos arenosos, cuja fertilidade era no início também relativamente alta, e também lá fez elevar os rendimentos da colheita, para além da medida usual de São Paulo. Essa fertilidade iludiu o colono sobre o real valor útil agrário. As consequências apareceram de modo intenso nos anos sessenta (ver Cap. VI).

O frontier do norte do Paraná, que avançou do oeste do rio Tibagi para o rio Paraná de 1930 até o fim dos anos 40 de modo relativamente lento, mas depois disso com grande velocidade até 1960 por causa do boom do café, não demonstra a sucessão de 'estágios de frontier' [frontier-stages] no sentido de Turner, no entanto proporcionou na composição de sua população "uma secção transversal da sociedade" [ $a$ cross section of society] (BOWMAN, 1931, p. 1).

A motivação da colonização na frente pioneira foi, na verdade, o desejo de ganho rápido. No entanto, as possibilidades sociais do pioneiro ascender para 'sitiante' 177 fazem surgir, no Norte Novo e Novíssimo, sob a nova camada social de pequenos proprietários, "um ar de permanência e um desejo de construir um futuro seguro" [an air of permanency and a desire to build a secure future] (DAMBAUGH, 1959, p. 22). A partir da observação subsequente da organização social do Norte do Paraná, conclui-se que esse desenvolvimento positivo não pôde influenciar e melhorar a situação precária e a contínua e alta mobilidade espacial dos trabalhadores rurais.

176 Em 1958, 31\% dos cafeeiros em São Paulo tinham mais de 30 anos de idade; em 141.000 ha de áreas cultivadas $7 \%$ com até mais de 50 anos (UNITED NATIONS, 1960, p. 26).

177 Proprietário de um sítio (pequena e média propriedade). 
Figura 3: Número de cafeeiros e produção de café de regiões de cultivo selecionadas do Brasil
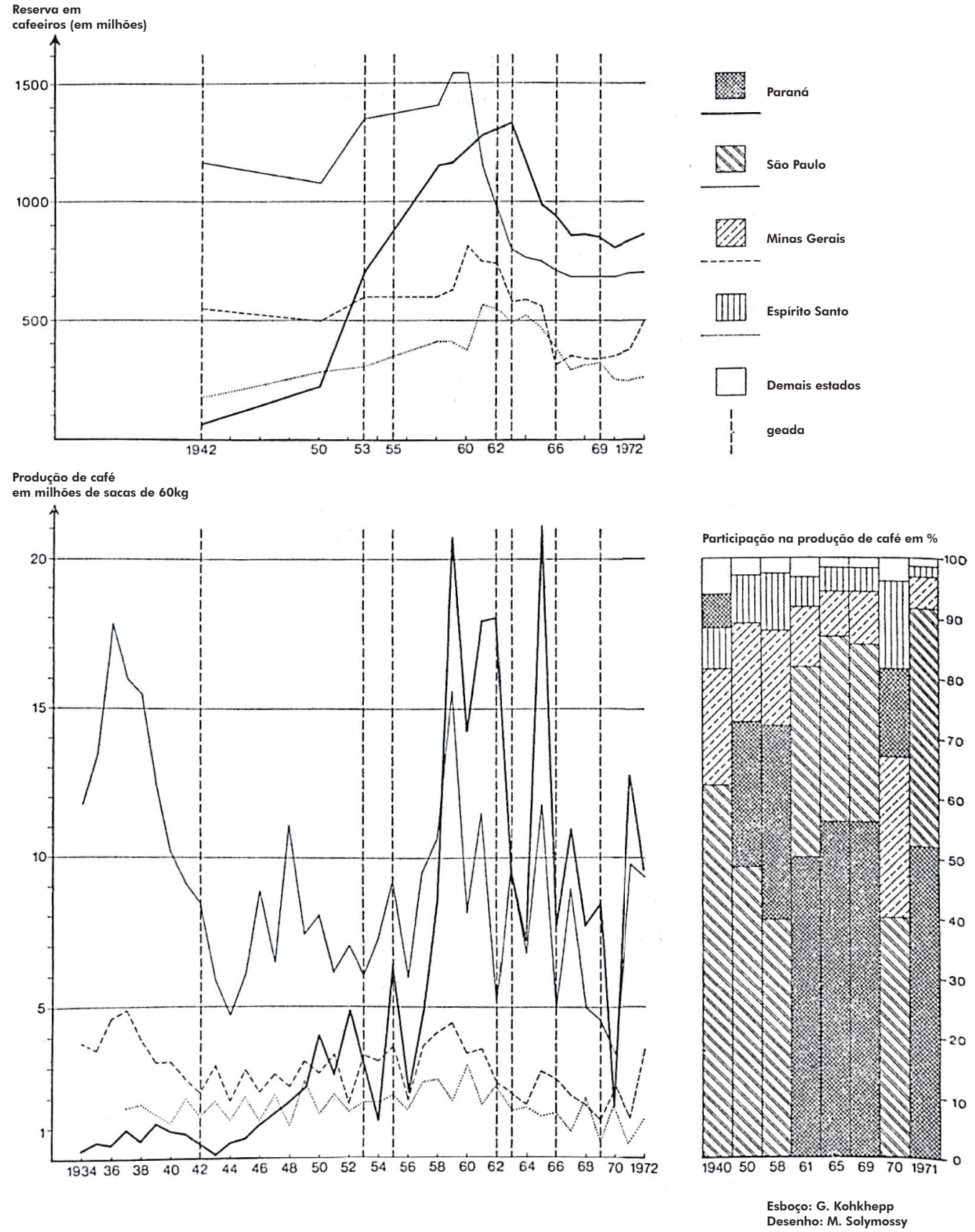

Fontes: IBC, Anuários Estatísticos do Café, 1965-1972. 


\section{ESTRUTURA DA ORGANIZAÇÃO SOCIAL RURAL E DA ORGANIZAÇÃO DE TRABALHO NO CULTIVO DE CAFÉ DO NORTE DO PARANÁ}

A estratificação da estrutura social rural mostra, na verdade, claras graduações entre os grupos principais. Claramente existem entre trabalhadores rurais e arrendatários inúmeras diferenças graduais, que resultam em relações de dependência diferenciadas, compromissos de trabalho distintos ou variantes diversas de pagamento (dinheiro, produtos, remuneração parcial).

Na observação das relações em todo o Brasil, chamam a atenção as incontáveis variantes regionais não só quanto às designações, mas também quanto às formas mesmas de dependência da população rural não autônoma. Os nomes atribuídos aos trabalhadores rurais mudam, em parte, conforme o produto de cultivo correspondente.

Também a estrutura social rural no Norte do Paraná é caracterizada dentro de grupos isolados por transições correntes e formas especiais. Na sequência, procura-se apresentar a organização social rural, sobretudo com o exemplo da economia cafeeira característica do Norte do Paraná.

\section{a) 'Volante' ou 'camarada'}

Na hierarquia da estrutura social agrária, o trabalhador migrante, conhecido como 'volante' ou 'camarada', encontra-se na camada social mais baixa. A designação 'volante' (do adjetivo 'instável', 'móvel'), circunscreve a alta mobilidade dessa camada social, cujos membros migram de plantação em plantação, tanto de São Paulo até o Paraná como dentro de áreas regionais isoladas no Paraná, à procura de trabalho.

O trabalhador migrante não tem uma colocação fixa e é contratado apenas temporariamente, tanto na colheita do café (junho - setembro no Paraná) quanto na colheita de algodão (março - maio), o que provoca migrações pendulares prolongadas entre o Paraná e São Paulo. São quase sempre pessoas jovens que encontram emprego a curto prazo em plantações e nas relativamente poucas lavouras grandes de café no Norte do Paraná, enquanto trabalhadores migrantes mais velhos e aqueles que vêm com a família são empregados apenas de mau grado.

Nos anos de colheitas fortes, períodos de trabalho intenso (cavas e mondas) ou estruturação de pastos e cercas, toda mão de obra torna-se necessária e a solicitação de 'braços' ou 'enxadas'178 é perceptível. Após os anos de geada, no entanto, o que se vê são trabalhadores migrantes procurando por trabalho nas ruas. As correntes espontâneas de trabalhadores migrantes trazem consigo problemas quase insolúveis para o Paraná, especialmente depois dos estragos de geadas e da colheita de café suspensa ou depois de colheitas ruins em São Paulo, já que há poucas possibilidades de trabalho.

Apesar de toda perseverança, os trabalhadores migrantes, fatalistas, esgotados e subnutridos, com frequência quase não têm condições físicas de executar com regularidade um trabalho pesado no campo. A isso se acrescenta o clima do inverno, com o qual não estão acostumados, sobretudo os nordestinos, e que provoca resfriados graves nos 'volantes' e suas famílias que moram em 'ranchos' ou casas coletivas sem aquecimento. Quase sem exceção infestados por doenças amébicas e verminosas, por ancilostomíase (parasitas nematóides) e frequentemente por esquistossomose ( $S$. mansoni), os trabalhadores migrantes são, como transmissores de doenças infecciosas tropicais, um problema grave para o Norte do Paraná. Uma grande parte deles está infectada pela malária, e também comprovou-se a ocorrência da Doença de Chagas ${ }^{179}$, incurável, em uma parcela relativamente alta. A preocupação com a subsistência e a possibilidade de guardar economias para os membros da família que ficaram para trás faz com que os trabalhadores migrantes trabalhem frequentemente sob condições indignas. A isso se acrescenta um sentimento peculiar acentuado de saudade ${ }^{180}$ diante do 'ambiente' do Norte do Paraná.

Para plantações maiores ou fazendas de café são preferíveis, com frequência, as chamadas 'turmas', grupos de 10 a 15 jovens trabalhadores, que se unem sob a coordenação de um líder

178 Frequentemente, o trabalhador rural simples é chamado, informalmente, de enxada.

179 Doença infecciosa provocada pelo Trypanosoma cruzi.

180 Três quartos dos 125 entrevistados responderam que estar 'longe da família e da nossa terra' era um dos principais motivos de insatisfação. 
de equipe de trabalho e realizam trabalhos sobre a terra somente em grupo. Essas equipes já desenvolveram uma consciência de grupo e não serão exploradas tão facilmente pelos proprietários de terras.

O pagamento dos trabalhadores migrantes se dá segundo acordo em dinheiro, no entanto, em uma colheita no máximo de 5 a 6 sacas de café ${ }^{181}$ por dia, rende para os trabalhadores apenas o mínimo para sobreviver. Um trabalhador temporário mal consegue um salário mínimo estipulado pelas novas leis trabalhistas. Mesmo que os salários de colheita sejam menores no Paraná do que em São Paulo, o rendimento maior das lavouras jovens de café do Paraná em melhor idade de produção resultam em um desempenho diário maior e, com isso, em possibilidade de ganho maior.

Uma grande parte das lavouras de café do Norte do Paraná está em pequenas e médias propriedades e pouco necessita de mão de obra adicional, já que a família do proprietário do 'sítio' e as famílias de colonos contratadas e ali domiciliadas cumprem uma grande parte do esforço de trabalho ${ }^{182}$. Em algumas das grandes fazendas, ao contrário, são necessárias várias centenas de trabalhadores temporários.

Segundo estimativas da Fetaep, o número de trabalhadores migrantes chega a atingir, em anos de boa colheita de café e algodão, mais de 300 mil pessoas que, sem seguro social durante a temporada de trabalho, vivem muitas vezes sob condições de higiene extremamente precárias e sobre cujos índices e variações não há quaisquer informações estatísticas exatas. ${ }^{183}$ Na grande maioria, são recrutados como trabalhadores migrantes nordestinos e mineiros, estes últimos provenientes do leste de Minas Gerais.

Como resultado da nova formulação da lei social agrária, o número de diaristas também aumentou nas lavouras de café. Eles moram, em geral, nos pequenos 'patrimônios' ou em áreas metropolitanas dos centros regionais e vão trabalhar por oito horas diárias em diversos trabalhos agrários ${ }^{184}$.

\section{b) Trabalhadores rurais}

O trabalhador rural com moradia fixa no 'sítio' ou na 'fazenda', o 'colono', tem em geral um contrato de trabalho fixo anual. A economia de 'colonato' é a forma tradicional da organização de trabalho no cultivo de café. O 'colono' cuida de 4 a 6 mil cafeeiros, que ele administra com sua família, sendo que recebe para isso um salário fixo em espécie para cada mil árvores ${ }^{185}$. A colheita do café é paga segundo a tarifa por saca, e as horas extras devem ser remuneradas, ao menos segundo a lei. Uma casa simples de madeira com cobertura de telhas, um lugar para o fogão e um poço são disponibilizados para o trabalhador. Para isso, 20\% do salário ${ }^{186}$ devem ser descontados para o aluguel da moradia.

A principal causa da atratividade das zonas pioneiras para os 'colonos' está na possibilidade de poder plantar culturas intermediárias para o próprio sustento, entre os carreadores de café novos, que ainda não estão em produção. Em áreas com lavouras de café em grande produção ou com lavouras mais antigas e com rendimentos mais fracos, por conta da absorção competitiva de nutrientes e - na região central do estado de São Paulo - da retenção da água pelas plantas, essas culturas de subsistência não podem ser empregadas sem que haja uma diminuição de produção no cultivo do café.

Muitos proprietários de terras no Norte do Paraná concedem aos 'colonos' - segundo acordo sobre o tipo de produto de cultivo e o número de carreadores no plantio de milho, feijão e arroz uma parte determinada da 'fazenda' ou do 'sítio' para cultivo paralelo durante os quatro primeiros

1811 saca de café na casca (em côco) = 40 quilos; 3 sacas não limpas = 1 saca de café limpo (beneficiado) com 60 quilos.

182 No município de Maringá, o percentual de trabalhadores temporários necessários como força de trabalho nos empreendimentos cafeeiros variou, de 1961 a 1963, entre 14 e 43\%, segundo o volume da colheita (NICHOLLS e PAIVA, 1969, p. 138).

183 Sobre isso, ver as análises de amostragem e os levantamentos estatísticos realizados pelo autor (ver Cap. IV, 3).

184 Quanto ao problema do sistema boia-fria no cultivo do café (ver Cap. VII, 4b).

185 1970: em média 200 cruzeiros (cerca de 170 marcos alemães) por 1.000 cafeeiros ao ano.

186 O salário total por mês, segundo o salário mínimo estipulado pela lei de 1970, deve alcançar para cada colono 170 cruzeiros, ou seja, algo como 140 marcos alemães. 
anos da lavoura de café, ou seja, até a primeira colheita ${ }^{187}$. Dos rendimentos das culturas, vão para o proprietário da terra de 20 a 50\% como arrendamento da terra, dependendo de cada contrato. O restante vai para a alimentação dos 'colonos', assim como para venda, sendo que o proprietário da terra tem preferência de compra. Através da venda dos produtos das culturas intermediárias, o 'colono' pode melhorar parcialmente os seus rendimentos até o dobro do valor de seu salário ${ }^{188}$.

Quando os cafeeiros entram na idade de produção, é então destinado aos 'colonos' um pequeno pedaço de terra, desfavorável para o plantio de café (fundo de vale), para utilização agrária ou também para manter alguns porcos ou uma vaca. Como esse pedaço terra muitas vezes se localiza distante da moradia, o 'colono' prefere as plantações paralelas no café, que são mais próximas. A suspensão de plantações paralelas no cultivo de café, antes da primeira colheita, frequentemente era motivo para que os trabalhadores rurais seguissem para uma nova plantação no frontier. Outros proprietários de terra - especialmente se tinham se comprometido com 'empreiteiros' consignavam aos 'colonos', desde o começo, um pequeno pedaço de terra fora da plantação de café para o uso próprio.

A fronteira climática do Norte do Paraná e o permanente risco de geadas originaram uma generalizada expansão temporal das plantações paralelas também depois do quarto ano. Depois dos anos de geada, desenvolveu-se um plantio intensivo de alimentos básicos que deve ter ajudado a superar a crise financeira de todo o negócio.

A nova ordem de salário na segunda metade dos anos 1960, baseada no salário mínimo mensal, trouxe uma reestruturação na utilização de culturas intermediárias no plantio de café. É proibido abater do salário do colono a parte do arrendamento das rendas da plantação paralela. Por outro lado, caso o proprietário da terra não tenha plantado mudas de café de modo algum, ele mantém para si a renda da colheita das respectivas plantações paralelas.

Com isso, no futuro, o 'colono' provavelmente tem a importante segurança do salário mínimo garantido por lei, mas não pode mais, como até então, melhorar muito sua situação financeira por meio da renda das plantações paralelas para poder comprar sua própria terra. A mobilidade social (ver p. 90ss.), com isso, existe para o trabalhador rural somente em dimensões insignificantes (ver Cap. VII, 4b).

Por outro lado, mantém-se a dependência total do proprietário da terra, que, nos pequenos e médios negócios, é atenuada frequentemente através da presença do proprietário e do estabelecimento de uma comunidade. Em estabelecimentos médios e grandes de maior magnitude, os administradores, que pensam em obter a maior comissão possível, dominam os 'colonos' de maneira mais rígida e, sem dúvida, se servem de um importante controle do aproveitamento do trabalho do 'fiscal', um tipo de vigia com posição privilegiada diante dos trabalhadores.

\section{c) Parceiros}

São inúmeras as formas de arrendamento no Brasil, fixadas por contatos orais ou escritos entre os proprietários de terra e os 'arrendatários'189. Em geral predominam os 'parceiros', que normalmente trabalham em associações familiares sem mão de obra desconhecida, com base no meeiro, terceiro, quartista etc. Segundo a relação de interesse do 'parceiro', ele é chamado de 'meeiro', 'terceiro' ou 'quartista'. No plantio de café, o meeiro é o mais comum (Foto 7). A forma de arrendamento ocorre em propriedades pequenas, médias e grandes. Como tempo mínimo de contrato de arrendamento foram fixados três anos, legalmente, a partir de $1966 .{ }^{190}$ Com isso teve-se uma melhora significativa, já que até então predominava apenas o curto período de um ano ou no máximo dois para contratos de arrendamento, e a rápida exploração dos solos aumentava com a redução do tempo de execução. Compreensivelmente, o arrendatário tentava obter a melhor colheita possível com o mínimo de investimento em fertilizantes e pulverizantes, pois um ano depois podia ser que o seu contrato com o proprietário da terra não fosse prorrogado.

187 Já no começo do século, fazendeiros paulistanos, temendo a diminuição da produção, fizeram ressalvas contra plantações paralelas na lavoura do café e proibiram seus colonos de plantar culturas intermediárias entre os cafezais.

188 Com relação à expansão mais recente, ver cap. VII, 4b.

189 As denominações para as formas de arrendatário são usadas diferentemente de acordo com a região: entre outras, arrendatário, rendeiro, parceiro, foreiro, quotista, locatário, vazanteiro (DIÉGUES, 1959, p. 95).

190 Fetaep (1967): Manual de legislação rural, art. 13, item IIa. 
Em geral o 'parceiro' não possui recursos financeiros. O proprietário da terra lhe empresta dinheiro e mercadorias, e com isso ele permanece em dívida, de acordo com a cota de arrendamento. No plantio de café, o 'parceiro' é obrigado a cuidar da plantação e a realizar a colheita. Utensílios e sementes são disponibilizados para o cultivo de alimentos básicos. Proporcionalmente, o proprietário da terra pode exigir do arrendatário o desembolso pelos fertilizantes e pulverizantes, de acordo com o preço de custo.

Além do cultivo de café, a parte do proprietário da terra junto ao rendimento da colheita compreende:
$10 \%$ no emprego da terra não trabalhada
$20 \%$ na arada e na instalação de uma moradia
$30 \%$ nas instalações adicionais (coberturas, cercas de pasto, bebedouros etc.)
$50 \%$ nos empregos adicionais de sementes, animais de tração, instalações e máquinas agrícolas

Arrendatários e parceiros - também no curso de colheita favorável - têm um padrão de vida consideravelmente melhor que os diversos grupos de trabalhadores rurais. Eles podem trabalhar de maneira autônoma, na sua maioria, com base nas diretrizes gerais estabelecidas. No Norte do Paraná, muitos antigos arrendatários aproveitaram a oportunidade para adquirir sua própria terra no frontier.

\section{d) Empreiteiro}

Uma forma especial na estrutura social agrária é o chamado 'empreiteiro', um fenômeno específico da zona pioneira, onde ele realiza como subempregador, por exemplo, o arroteamento para o proprietário da terra. No frontier cafeeiro, ele é especializado no primeiro estágio da plantação do café. Ele cuida da plantação de café até a idade de produção e, por esse motivo, é chamado também de 'formador'.

Sob sua orientação, são dispostas covas na distância de aproximadamente 3,7 x 3,7 metros, com $40 \mathrm{~cm}$ de diâmetro e com 20 a $30 \mathrm{~cm}$ de profundidade, nas quais são colocadas de 6 a 4, em parte até 15 (!) sementes, e então levemente cobertas de terra ${ }^{191}$. Cobre-se as cavidades com talhas de madeira para fazer sombra e para proteção contra chuvas fortes. No crescimento das plantas, as madeiras são dispostas como grades para que o processo de crescimento subsequente não seja prejudicado e, pouco depois, totalmente removidas. Depois de um ano, todas as mudas, de 4 a 6, serão retiradas. O cafeeiro, segundo o esquema de plantio brasileiro, consiste portanto de diversas plantas. ${ }^{192}$ Essa atividade de extrema responsabilidade é executada pelo 'empreiteiro' com grande dedicação, também por interesse próprio, no que diz respeito ao que lhe cabe segundo as condições contratuais.

Nos contratos entre os proprietários das terras e os 'empreiteiros', há o formato de 4, 5 e 6 anos, de modo que, com a duração mais longa do contrato, diminui o rendimento do proprietário da terra, e a do 'empreiteiro' aumenta. Algo parecido acontece com as possibilidades de ganho (Tabela 11).

O contrato de 4 anos requer altos investimentos do proprietário da terra. Esse formato de contrato é o mais difundido em negócios médios e grandes; visto em conjunto, porém, é relativamente raro, já que o proprietário capitalizado prefere implementar a plantação de café com trabalhadores pagos - e por isso mais controláveis - e também ele mesmo comercializar o primeiro rendimento da colheita (KOCH-WESER, 1957, p. 63). Para o 'empreiteiro' a vantagem consiste no fato de ele poder começar com o trabalho mesmo sem nenhum capital.

191 Sobre viveiros modernos, ver Cap. VIII, 3.

192 Depois de se ter considerado por longo tempo a folhagem abundante daí decorrente como vantagem para o sombreamento da própria planta ou proteção contra geada, em novas plantações financiadas pela IBC só podem ser colocadas três sementes em cada cova, para o melhor desenvolvimento do cafeeiro. 
Tabela 11: Formas de contrato entre proprietários de terras e empreiteiros no cultivo de café no Norte do Paraná

\begin{tabular}{|c|c|c|c|c|c|}
\hline $\begin{array}{l}\text { Duração do } \\
\text { contrato em } \\
\text { anos }\end{array}$ & $\begin{array}{l}\text { Investimentos do } \\
\text { proprietário da terra }\end{array}$ & $\begin{array}{l}\text { Investimentos do } \\
\text { empreiteiro }\end{array}$ & Ganho do empreiteiro & $\begin{array}{l}\text { Ganho do proprietário } \\
\text { da terra }\end{array}$ & \\
\hline 4 & $\begin{array}{l}\text { Derrubada da mata } \\
\text { Casa de madeira } \\
\text { Estradas } \\
\text { Poços } \\
\text { Sementes de café } \\
\text { Instrumentos de tra- } \\
\text { balho } \\
\text { Animais de tração e } \\
\text { de montaria } \\
\text { Veículos }\end{array}$ & $\begin{array}{l}\text { Remover a madeira, plan- } \\
\text { tar o café, cuidar dos ca- } \\
\text { feeiros, cortar, carpir, lim- } \\
\text { par por } 4 \text { anos }\end{array}$ & $\begin{array}{l}\text { Determinação soma/ } \\
\text { cova; } \\
\text { produto da venda da } \\
\text { colheita de café do } 1^{\circ} \text { ao } \\
4^{\circ} \text { ano. }\end{array}$ & $\begin{array}{l}\text { Mantém a plantação } \\
\text { produtiva de café de- } \\
\text { pois de } 4 \text { anos, ou seja, } \\
\text { antes da primeira co- } \\
\text { lheita. }\end{array}$ & 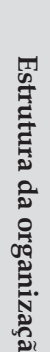 \\
\hline 5 & $\begin{array}{l}\text { Derrubada da mata } \\
\text { Casa de madeira } \\
\text { Sementes de café }\end{array}$ & $\begin{array}{l}\text { Vide acima. } \\
\text { Adicionalmente, constru- } \\
\text { ção da estrada e do poço, } \\
\text { instrumentos de trabalho } \\
\text { por custo próprio }\end{array}$ & $\begin{array}{l}\text { Colheita do café do } 4^{\circ} \text { e } \\
\text { do } 5^{\circ} \text { anos e plantações } \\
\text { paralelas do } 1^{\circ} \text { ao } 4^{\circ} \\
\text { anos. }\end{array}$ & $\begin{array}{l}\text { Plantações produtivas } \\
\text { de café depois do } 5^{\circ} \\
\text { ano. }\end{array}$ & 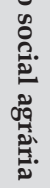 \\
\hline 6 & Nenhum & $\begin{array}{l}\text { Trabalho completo por } \\
\text { custo próprio; em parte } \\
\text { delegação de trabalhos a } \\
\text { terceiros }\end{array}$ & $\begin{array}{l}\text { Colheita de café do } 4^{\circ} \text { ao } \\
6^{\circ} \text { anos e plantações pa- } \\
\text { ralelas do } 1^{\circ} \text { ao } 4^{\circ} \text { anos. }\end{array}$ & $\begin{array}{l}\text { Plantações produtivas } \\
\text { de café depois do } 6^{\circ} \text { ano }\end{array}$ & \\
\hline
\end{tabular}

Fonte: Pesquisas próprias do Autor em 1970.

Em contratos de 5 anos, o empreiteiro deve ter algumas reservas para poder construir estradas e poços às próprias custas. Além dos rendimentos nas plantações paralelas, seu ganho é a primeira colheita do café (no quarto ano, bastante limitada) e a segunda (no quinto ano, bem maior). Essa forma de contrato se expandiu, em geral, nas propriedades de porte médio.

A forma de contrato de 6 anos exige meios financeiros maiores do empreiteiro, que se torna empresário por um tempo e recebe do proprietário da terra apenas "o mato em pé e a água no córrego", segundo a formulação tradicional do contrato. O empreiteiro passa os trabalhos menores para terceiros, como, por exemplo, a derrubada de floresta para grupos de lenhadores e fazer as picadas e limpeza do solo para colonos, cujo pagamento o próprio empreiteiro deve assumir. Em condições climáticas favoráveis, o ponto de partida para o empreiteiro, nessa forma de contrato, é naturalmente o melhor, pois como ganho principal ele recebe a colheita do quarto e do sexto anos (Tabela 11), além dos rendimentos das plantações paralelas ${ }^{193}$. Com o benefício alcançado a partir disso, os empreiteiros adquirem com frequência a própria terra, ascendem na escala social e se tornam plantadores de café autônomos na fronteira pioneira avançada. Mas existem também empreiteiros que, enquanto comerciantes, interessamse principalmente pelos produtos das plantações paralelas.

No Norte do Paraná, para os empreiteiros com seis anos de contrato o perigo de uma geada dentro de um período tão longo de tempo é sem dúvida maior. Depois do quarto ano, o risco de geada recai totalmente sobre o empreiteiro. Para ele, geadas no terceiro e quinto anos são especialmente severas, porque eventualmente ele pode não alcançar uma colheita de café plena e não lucrar sobre seus investimentos financeiros.

Para o pequeno emédio proprietário de terra sem capital ou sem disposição para riscos deinvestimento, o contrato de seis anos era a forma ideal da economia cafeeira: sem qualquer investimento, ele adquiria depois de seis anos uma plantação de café com produção plena. Sob o ponto de vista econômico, embora com as três primeiras colheitas de café, destinadas aos empreiteiros, ele perdesse mais do que havia

193 No que diz respeito às plantações paralelas, certas prescrições são feitas aos empreiteiros em geral pelos proprietários. É permitido o cultivo de milho, feijão, arroz montês e batata. São proibidas as plantações de abóbora, mandioca, batata-doce e todas as plantas de raízes profundas, que podem prejudicar os cafeeiros jovens. A partir do terceiro ano, podem ser plantadas apenas duas fileiras de milho ou três de feijão, arroz ou - apenas recentemente - trigo. No quarto ano, uma fileira a menos, para não prejudicar o crescimento dos cafeeiros. 
custado o investimento na plantação, evitava assim, por outro lado, nas regiões periféricas meridionais do Norte do Paraná, perdas diretas de capital próprio por meio de danos causados pela geada nas plantações de café jovens, particularmente sensíveis.

Além disso, há ainda inúmeras variantes de contrato para o empreiteiro, entre outras a transferência de uma parte (em geral 20\%) da terra cafeeira lavrada e cultivada por ele, depois de transcorridos 6 anos. Para muitos empreiteiros sem recursos, essa é a forma direta de ascensão a proprietário de terra.

A classe social dos empreiteiros revela uma diferenciação interna bastante evidente, que vai do subempreiteiro autônomo com reserva de capital, que trabalha com subgrupos e formas diferentes de arrendamento e subarrendamento, até o arrendatário sem recursos, que organiza e toma conta da plantação de café graças a sua experiência, com o objetivo de adquirir propriedade privada por meio do rendimento da venda das duas primeiras colheitas de café.

A forma original do empreiteiro passa então por um processo de transformação e se aproxima mais da forma de arrendatário meeiro: o frontier alcança o rio Paraná e assim não existem mais terras virgens próprias para o cultivo de café no estado do Paraná, tampouco no sul do Mato Grosso do Sul.

No norte do Paraná, cabe incluir os arrendatários com contratos de arrendamento favoráveis e empreiteiros com 4 anos de contrato em uma classe média rural mais baixa, em si bastante diferenciada. Empreiteiros com contratos de longo prazo e pequenos proprietários (algo como 10 a 25 ha) ${ }^{194}$ ocupam, no cultivo de café, uma classe média elevada para os padrões brasileiros.

\section{e) Proprietários de terra}

Dentro da camada social autônoma dos proprietários de terra há também grandes diferenças. Excetua-se aqui o grupo dos 'ocupantes'195, intrusos e posseiros (ver Cap. III, 3), que já nos anos 1970 está pouco presente no Norte do Paraná. Esse grupo, embora sem legitimação jurídica, caracteriza-se administrar com a mesma liberdade dos demais proprietários de terra, no entanto são-lhe recusados os créditos.

$54 \%$ de todos os empreendimentos agrários no Norte Novo e Norte Novíssimo do Paraná têm uma área entre 10 e 40 ha. No cultivo do café, $58 \%$ de todos os empreendimentos possuem entre 4.000 e 16.000 cafeeiros (IBC-OEA, 1964). Aí se incluem os sítios, atividades de pequeno porte, que em grande parte são geridas por proprietários de terra também com a ajuda de algumas famílias de colono (Fotos 4, 5).

Nos empreendimentos de médio porte (até aprox. 65.000 cafeeiros, 22\% deles) predominam três formas de gestão do cultivo agrícola. Os empreendimentos de médio porte menores são realizados pelos proprietários e trabalhadores rurais em conjunto. Em parte, o proprietário rural mora no município mais próximo e se desloca quase que diariamente para a propriedade, onde atuam alguns parceiros, trabalhadores rurais ou um administrador (Foto 3), dos quais o último recebe casa, salário e uma parte do rendimento da colheita.

O absentismo aparece, em geral, nos empreendimentos de médio porte maiores, que garantem ao proprietário um rendimento muito bom nos anos normais de colheita. O proprietário, que vive geralmente na capital Curitiba ou em grandes cidades do estado de São Paulo, emprega um administrador, que organiza o negócio de maneira geral, paga a mão de obra e recebe entre 40 e $50 \%$ da colheita. 50\% do total líquido da colheita pertence ao proprietário, que aparece 3 a 4 vezes no ano sobretudo em tempo de colheita e para o controle geral. A designação dos empreendimentos de médio porte maiores variam entre 'sítio' e 'fazenda'.

O último tipo de atividades de médio porte começa no cultivo de café de aprox. 60 a 70.000 árvores. No entanto, suas fronteiras também são fluidas e os critérios para demarcação de uma fazenda (ver Cap. IV , 4), sobretudo as próprias instalações de preparo e organização da comercialização, aparecem com frequência somente nos empreendimentos com mais de 100.000 árvores (Foto 10), levando em consideração as diferenças regionais. Entretanto, essas dimensões aparecem no Norte

194 Os proprietários de terra com menos de 10 ha (ou seja, $\varnothing$ de aprox. 3 a 4 ha de café) devem eles mesmos agregar arrendamentos para alcançar a melhoria de suas condições de existência no cultivo do café. Para os proprietários de chácara, pequenos vendedores ou comerciantes, pequenas propriedades ou minifúndios significam apenas uma subaquisição na periferia da cidades.

195 Gestores de cultivo de terras alheias, sem necessidade de recolhimento de impostos, com ou sem consentimento dos proprietários ausentes. 
do Paraná em menos de $2 \%$ dos empreendimentos de cultivo do café. ${ }^{196}$ Mais administradores à base de ordenado dirigem os negócios da fazenda, em geral com um bônus nos ganhos da colheita, e possuem um padrão e estilo de vida frequentemente ainda mais altos que os dos pequenos proprietários autônomos.

A classe dos latifundiários investe grande parte do seu capital em imóveis, especulações financeiras, nas indústrias de construção locais (p. ex. Londrina) e em participações em empreendimentos industriais dos grandes centros urbanos. O escoamento de capital para São Paulo é considerável.

A influência dos chamados 'maquinistas' na zona rural é até hoje significativa, já que o sistema cooperativo no cultivo de café do Norte do Paraná se desenvolveu somente no começo dos anos 1960. Esses maquinistas possuem os equipamentos para o processamento e classificação do café e têm sua sede nos pequenos patrimônios ou nas principais localidades municipais. Os proprietários de atividades de pequeno porte e de médio porte menores enviam suas colheitas para os maquinistas e são totalmente dependentes deles, porque estes pré-financiam as colheitas aos cafeicultores com o abatimento de uma determinada porcentagem do café limpo. Os proprietários das instalações para beneficiamento do café tomam créditos dos bancos locais e, com frequência, são dependentes de firmas nacionais ou estrangeiras de exportação de café no âmbito regional ou suprarregional. Essas firmas compram as colheitas por atacado na área de cultivo de café, em parte sob concorrência acirrada.

As 'cooperativas' do café procuram reduzir a pressão de comercialização sobre os pequenos proprietários, tentando conseguir elas mesmas as possibilidades diretas de exportação para os seus membros, o que é possível contudo apenas para as grandes cooperativas.

As fazendas de café possuem suas próprias instalações de beneficiamento e, com frequência, também relações diretas com firmas de exportação nos portos de escoamento de Paranágua ou Santos.

O pagamento exigido para o trabalhador rural, com base no salário mínimo mensal prescrito pela lei, é absolutamente insuficiente. Apesar disso, uma parte dos plantadores de café procura ainda no contexto do início dos anos 1970 evitar esse pagamento. O governo militar se esforça por garantir a instituição do salário mínimo no meio rural, no entanto, até então consegue controlar apenas o cumprimento das prescrições legais para os trabalhadores da indústria.

Se esse desenvolvimento significa uma tentativa concebida para o Brasil rural de modo geral com o intuito de regulamentar a situação financeira das classes sociais mais inferiores, então a sua prescrição rígida causa uma situação estruturada do cultivo de café totalmente diferente e também um 'congelamento' das chances de ascensão social dos trabalhadores rurais para meeiro. Atualmente, deixa-se de considerar os rendimentos das plantações paralelas antes incluídos no cálculo econômico dos trabalhadores rurais e pequenos arrendatários ativos e, por causa do salário mínimo muito baixo, impede-se a permeabilidade atual das classes sociais, que via de regra está associada à dinâmica das zonas pioneiras produtivas.

A estrutura social agrária atual na zona de cultivo cafeeiro do Norte Novo e Norte Novíssimo do Paraná é apresentada na Figura 3 mais uma vez de modo esquemático e resumido. Isso proporciona uma visão geral sobre a estrutura das classes sociais rurais e suas relações, funções e situação jurídica.

Para o desenvolvimento da estrutura social na zona de cultivo de café no Norte do Paraná, a mobilidade social ligada à espacial tem um significado peculiar, que se manifesta diferentemente nos grupos e classes específicos.

196 No entanto, os proprietários de terra realizavam com frequência mais atividades de médio e pequeno porte por meio de aquisição adicional. Essas atividades aparecem de tal modo nas estatísticas que, em parte, senão totalmente, acabam designando seus proprietários como fazendeiros. 
Figura 3a: Esquema da estrutura social agrária na área de cultivo de café no Norte do Paraná

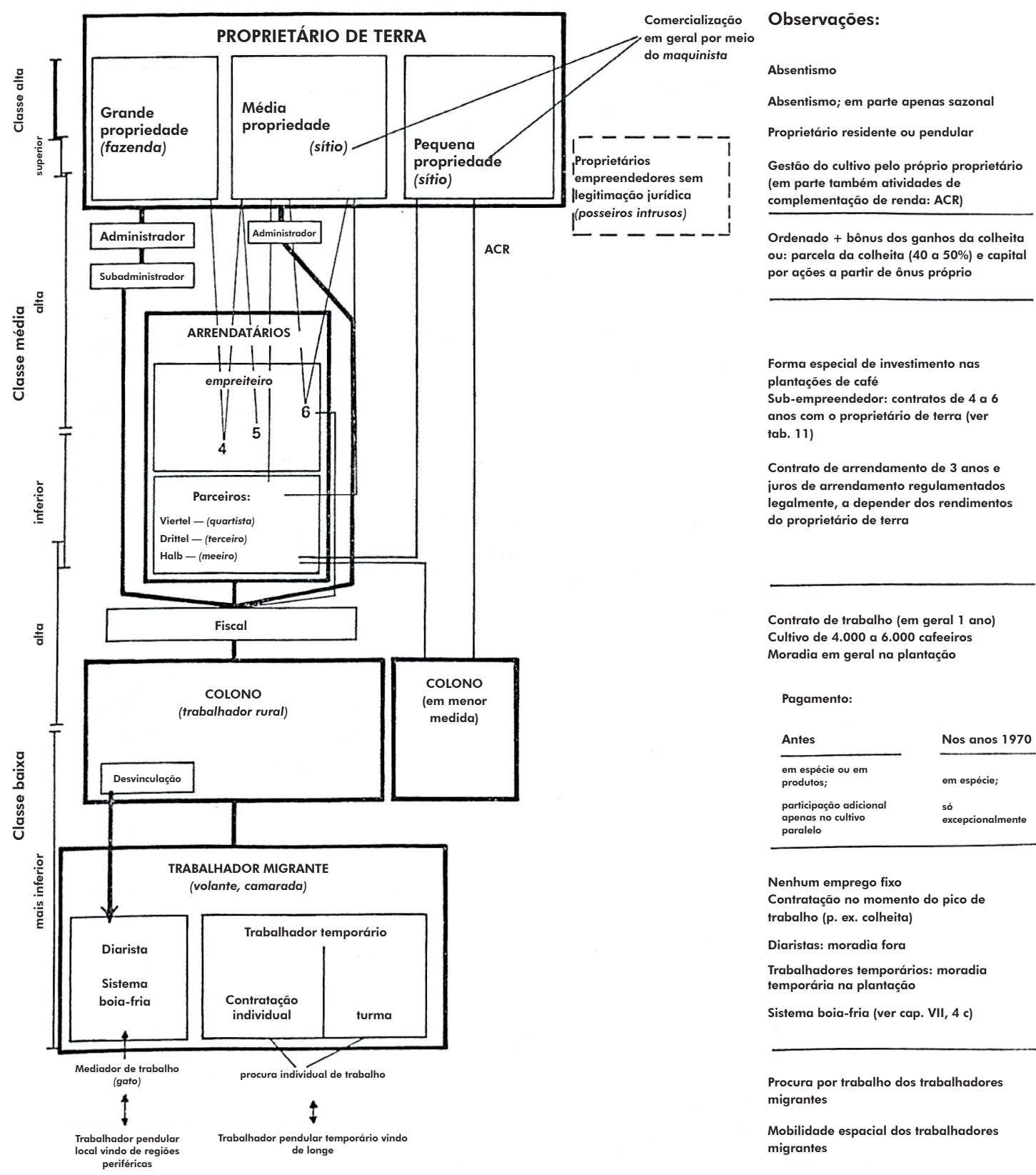




\section{MOBILIDADE SOCIAL E ESPACIAL ESPECÍFICA DE GRUPOS E CLASSES NO ÂMBITO DA ECONOMIA CAFEEIRA PARANAENSE}

\section{a) Sobre o conceito de mobilidade}

Nas Ciências Sociais, compreende-se 'mobilidade' como "[...] o movimento de pessoas de uma posição para uma outra" (BOLTE, 1969, p. 1). Sorokin (1927) designa mobilidade 'vertical' e 'horizontal' como as formas principais da mobilidade social, sendo que 'vertical' significa a ascensão ou queda de indivíduos ou de grupos dentro de um sistema social, enquanto mobilidade 'horizontal' significa '[...] uma mudança na posição social que não encerra em si uma mudança de classe" (HORSTMANN, 1969, p. 43).

No entanto, o verdadeiro componente horizontal da mobilidade é dado por pessoas ou grupos em deslocamento, o que é chamado de mobilidade 'regional' ou 'espacial' (HORSTMANN, 1969, p. 43), de "migração" no sentido de um movimento no espaço ou também pelo termo 'mobilidade geográfica' (ALBRECHT, 1972, S. 23).

Frequentemente, a motivação para a mobilidade espacial é o desejo de se tornar socialmente móvel, isto é, de buscar uma chance de ascensão na hierarquia de classes sociais em uma nova posição.

A mobilidade espacial pode ser analisada segundo o seu curso e seu alcance geográficos; a peridiocidade e tempo de permanência em um lugar particular; seu transcurso organizador; motivos socioeconômicos e segundo o tamanho e composição dos grupos migrantes (HORSTMANN, 1969, p. 48; ALBRECHT, 1972, p. 33 ss.).

Em seguida, serão investigadas a mobilidade social e a espacial de diferentes classes sociais agrárias, assim como de grupos étnico-sociais selecionados dentro dessas classes, no caso da economia cafeeira no Norte do Paraná.

Antes disso, no entanto, cabe apresentar ainda uma breve visão de conjunto sobre o a evolução populacional.

\section{b) Evolução populacional}

O avanço do frontier do café no Norte do Paraná, de leste a oeste, trouxe consigo migrações internas prolongadas, que atingiram o seu apogeu entre 1950 e 1960 com a ocupação de terras em áreas do norte do Paraná ainda desocupadas ${ }^{197}$.

Nas décadas de 1950 e 1960, a população total da área estudada cresceu de 552.000 para 1,89 milhões, ou seja, em 242\% (Tabela 6, p. 303, Anexo; Tabela 12, p. 305, Anexo). No transcurso temporal da frente pioneira que avançava, a comparação da evolução populacional do Norte Novo e do Norte Novíssimo mostra que há, frente ao Norte Novo, um adiamento de fases do fluxo principal para as novas regiões colonizadas do Noroeste do Paraná:

\section{População em 1000}

$\begin{array}{llll} & \text { Norte Novo } & \text { Norte Novíssimo } & \text { Total } \\ 1940 & 94 & 23 & 117 \\ 1950 & 479 & 73 & 552 \\ 1960 & 1110 & 778 & 1889 \\ 1970 & 1479 & 1529 & 3008\end{array}$

Dentro dessa evolução peculiar do Norte do Paraná, a porcentagem da população rural abrange, até 1960, um total de $74 \%$ no Norte Novo e $86 \%$ no Norte Novíssimo. A evolução populacional mais recente na última década não foi aqui considerada, pois a apropriação das terras ocorreu na maior parte até 1960 (ver Cap. VIII, 2).

197 A média anual da taxa de crescimento da população paranaense compreende 7,2\% nesta década. 
Enquanto a população rural na região de Londrina apresentou o menor crescimento - 66\% de 1950 a 1960 - , as regiões de Apucarana (colonização das regiões periféricas do nordeste) e Maringá (avanço na direção de Ivaí) presenciaram um aumento da sua população rural em três ou quatro vezes. No Norte Novíssimo foram registrados crescimentos de sete a doze vezes, a depender da região (Tabela 6, p. 303, Anexo; Tabela 12, p. 305, Anexo).

No ano de 1940, 17\% da população paranaense não era nascida nesse estado. Em 1950, isso já correspondia a $31 \%$ da população total do estado ${ }^{198}$, sendo que essa evolução se atribui quase que exclusivamente à migração interna de São Paulo para o frontier do café no Norte do Paraná. 53\% da população que imigrou vêm de São Paulo, $24 \%$ de Minas Gerais e cerca de $8 \%$ do Nordeste. Apenas uma parcela de $15 \%$ provinda de Santa Catarina e do Rio Grande do Sul se opôs à migração interna dos estados do norte para a região cafeeira do Norte Novo e Norte Novíssimo. Aquela pertence sobretudo ao movimento de expansão dos colonos teuto e ítalo-brasileiros para as florestas subtropicais do Sudoeste e Oeste do Paraná (CIBPU, 1958, I, p. 3637; TORRES, 1957, p. 166). ${ }^{199}$

Na próxima seção são investigadas a procedência geográfica (segundo local de nascimento ou estado) e a mobilidade espacial e social da população que imigrou para o Paraná em duas áreas regionais determinadas, a partir de diferentes fases de evolução. Também faz-se necessário empreender uma tentativa de diferenciação dos dados para grupos étnico-sociais individuais.

\section{c) Mobilidade espacial e social das classes sociais agrárias, assim como de grupos étnico-sociais selecionados}

A procedência dos proprietários de terra atuais é analisada por meio de dois exemplos. ${ }^{200}$ Um deles é Mandaguari (Norte Novo), pesquisada na primeira fase da metade da década de 1930, e outro Umuarama (Norte Novíssimo), na segunda metade dos anos 1950.

Tabela 13: Procedência dos proprietários de terra em Mandaguari e Umuarama (segundo local de nascimento; parcela em \%)

\begin{tabular}{|c|c|c|}
\hline & \multirow[b]{2}{*}{ Mandaguari } & \multirow[b]{2}{*}{ Umuarama } \\
\hline & & \\
\hline São Paulo & 61 & 53 \\
\hline Minas Gerais & 20 & 17 \\
\hline Nordeste & 1,5 & 11 \\
\hline Rio de Janeiro & 1 & 3 \\
\hline Paraná & 6 & 3 \\
\hline Santa Catarina & 1 & 2,5 \\
\hline Rio Grande do Sul & 0,5 & 2,5 \\
\hline \multirow[t]{2}{*}{ Exterior } & 9 & 8 \\
\hline & 100,0 & 100,0 \\
\hline
\end{tabular}

Fonte: Entrevistas próprias do Autor, 1970.

Ambos os estudos de caso mostram que a absoluta maioria dos proprietários de terra nos anos 1970, no Norte Novo e Novíssmo, vem de São Paulo. Minas Gerais segue com uma diferença enorme. A quantidade de estrangeiros imigrados sem recurso, que hoje dispõem de terra, é considerável ${ }^{201}$.

198 Com isso, o Paraná foi ultrapassado apenas pelo Distrito Federal (43\%).

199 Não há dados estatísticos correspondentes para o ano de 1960.

200 As entrevistas e investigações foram realizadas pelo autor em 1970: a) em Mandaguari, com 311 membros da Cooperativa dos Cafeicultores; b) em Umuarama (Gleba Jacaratiá), com 288 proprietários com título de propriedade (cadastro de terras da CMNP e entrevistas próprias). Cf. também Mapa 11.

201 Em todo o Norte Novo e Novíssimo, existem casos de ascensão social rápida por causa da situação peculiar das zonas pioneiras. É mencionado aqui apenas o exemplo de um galiciano, hoje assentado em Londrina, mas que imigrou em 1928 sem recursos, veio para o Norte do Paraná via São Paulo, atuou primeiramente como garçom, depois no ramo de transporte 
No caso dos membros da cooperativa de cafeicultores em Mandaguari, ${ }^{202}$ pôde-se determinar um padrão da procedência geográfica dentro do estado de São Paulo:

$28 \%$ provêm da região de Mogiana, no nordeste de São Paulo; 10\% do norte, na região da Alta Araraquarense e $6 \%$ da região de fronteira com Minas Gerais; $12 \%$ do noroeste e $16 \%$ da zona paulista. Do sul e sudoeste, da alta e da baixa Sorocabana, imigraram 7 e $9 \%$, respectivamente, e, das regiões restantes do estado, $12 \%$. Em meados dos anos 30, a ampla dispersão das regiões de procedência dentro do estado de São Paulo aponta para uma tendência bastante vasta de emigração para o Paraná, sendo que os pontos principais ficavam nas antigas zonas de plantação de São Paulo (NE, E, centro).

A partir de uma amostra aleatória da entrevista sobre a posição social antes da aquisição de terra no Norte do Paraná, ${ }^{203}$ depreende-se que $22 \%$ já tinham propriedade (com plantação de café) em São Paulo $^{204}$ (das quais $90 \%<25$ alq. paul. $=65$ ha), enquanto que anteriormente $30 \%$ atuavam no cultivo de café como arrendatários (meeiro) e 25\% como empreiteiros (em São Paulo, em parte também já no Norte Velho do Paraná). Dos 23\% restantes, estão os estrangeiros imigrados recentemente; membros de profissões livres e comerciantes que antes não haviam se dedicado ao cultivo do café; e também uma quantidade extremamente baixa de antigos trabalhadores rurais. ${ }^{205}$ Dos que vieram de São Paulo, $45 \%$ eram de ascendência italiana, que, quase sem exceção, atuavam como arrendatários ou empreiteiros no cultivo do café antes da sua migração interna.

Dos proprietários de plantações de café, na maioria pequenos proprietários de terra, apenas 32\% moram em sua propriedade, enquanto $2 \%$ vivem parte na propriedade, parte na cidade (Mandaguari). $36 \%$ declararam Mandaguari como principal moradia, 30\% outras localidades do município. Apenas $66 \%$ se denominaram cafeicultores sem outra ocupação secundária ou principal. 8\% dos restantes são comerciantes, $7 \%$ médicos ou dentistas, $4 \%$ advogados e notários. Esses são, na maior parte, pertencentes à geração de filhos de imigrantes e, em menor número, imigrantes tardios que adquiriram plantações de café como investimento de capital, por causa de suas boas rendas.

O exemplo de Umuarama (Gleba Jacaratiá/CMNP) compreende a migração interna ocorrida 20 anos mais tarde. A porcentagem de proprietários rurais provenientes de São Paulo também predomina com 53\%. Com base em consulta detalhada e na avaliação das informações no registro da CMNP, foi averiguado que $55 \%$ dos imigrantes paulistas são de ascendência italiana, $38 \%$ luso-brasileira, $4 \%$ japonesa e 3\% de outra ascendência. Em Umuarama, do número total de compradores de terra imigrantes, 53\% são luso-brasileiros, 35\% ítalo-brasileiros, $4 \%$ de ascendência japonesa e $8 \%$ estrangeiros (4\% japoneses, italianos, portugueses, espanhóis e outros europeus). ${ }^{206}$

Os proprietários de terra de ascendência italiana são quase exclusivamente descendentes dos trabalhadores rurais italianos que, desde 1888, já migravam para São Paulo. ${ }^{207}$ Quanto aos estágios de

(construção de ferrovias, transporte de imigrantes), vendeu terras, começou em 1941 com a criação de gado paralela ao cultivo de café e, em 1959, importou zebu, raça de gado indiana, apesar de ser proibido. À época desta pesquisa ele possui a criação de zebu mais significativa do sul do Brasil, além da maior empresa de ônibus do país (350 ônibus), e deve ser um dos homens mais ricos do Norte do Paraná.

202 Dos 311 membros, apenas 42\% têm sua propriedade no município de Mandaguari. A ampla zona de alcance da cooperativa (Mapa 56) permite considerar os resultados das entrevistas, feitas em 1970, aplicáveis também a amplas regiões do Norte Novo e Novíssimo.

203 Dos 45 entrevistados provindos de São Paulo ou Minas Gerais (relação 3:1), sendo 30 com propriedade em Mandaguari, 41 puderam responder às perguntas por si mesmos ou por seus pais.

204 Cerca de um terço dessas pessoas mantiveram sua residência principal no estado de São Paulo ou regressaram para lá após alguns anos de gestão de suas atividades paranaenses e da nomeação subsequente de um arrendatário ou administrador.

205 Apenas um entrevistado declarou ser essa sua atividade mais antiga.

206 Um exame comparativo de 304 proprietários de terrenos registrados, na cidade de Umuarama, mostra os seguintes dados de origem regional e étnica: 47\% são de São Paulo (dos quais 55\% são de ascendência luso-brasileira, 32\% de italiana e $8 \%$ de japonesa), $14 \%$ estrangeiros (japoneses, portugueses, sírios, italianos e outros europeus), $12 \%$ do Paraná, $11 \%$ do Nordeste, $9 \%$ de Minas Gerais, 3\% de Santa Catarina, 2\% do Rio Grande do Sul, 2\% do restante do Brasil.

Do número total de proprietários de datas (terrenos urbanos): $59 \%$ são de ascendência luso-brasileira, 23\% de italiana e 5\% de japonesa, $5 \%$ são japoneses, $4 \%$ portugueses, $3 \%$ sírios e $1 \%$ de outras nacionalidades. - A comparação com proprietários de lotes rurais mostra, na cidade de Umuarama, um forte retrocesso dos proprietários de terrenos de ascendência italiana, em contraposição ao aumento dos de ascendência luso-brasileira e japonesa e à porcentagem da entrada de portugueses e sírios, que no Brasil se ocupam tradicionalmente do comércio.

207 As principais regiões de emigração na Itália foram Vêneto, Piemonte, Abruzos, Ligúria, Campânia, Sicília, Lombardia, Emilia e Calábria. Quase 90\% dos trabalhadores rurais italianos, no Paraná, vieram de Vêneto (BALHANA, 1956, p. 481; ROCCHETTI, 1958). 
trabalhadores rurais, pequenos arrendatários e empreiteiro, eles progrediram profissionalmente para proprietários rurais autônomos, no Norte Novo (por exemplo em Mandaguari) e no Norte Novíssimo (por exemplo em Umuarama). Apenas pouco mais de 5\% deste grupo já havia alcançado esse estágio em São Paulo.

Os resultados das entrevistas do Autor sobre a proveniência geográfica e étnica dos trabalhadores rurais da gleba Jacaratiá, no Município de Umuarama, se reflete no Mapa 23208: forte predominância de paulistas e de ascendência italiana, entre estes 'sitiantes'. A parcela relativamente alta (11\%) de proprietários de terra provindos do Nordeste do Brasil (sobretudo da Bahia), na maioria antigos trabalhadores rurais e pequenos arrendatários (ver Tabela 13, p. 99), demonstra que, no Norte Novíssimo, a estratificação social aponta de modo satisfatório para uma permeabilidade vertical. Ademais, nas zonas pioneiras do Oeste na segunda fase de expansão consideravelmente mais nordestinos tiveram chances de ascensão social do que nos dois decênios anteriores, por exemplo, na região de Mandaguari (1,5\%).

Com relação à migração ligada à expansão cafeeira, provinda do estado de São Paulo, Minas Gerais e do Nordeste, em contraposição aos valores de Mandaguari (22\%), o exame da posição social antes da aquisição de terra no Norte Novíssimo do Paraná mostra que apenas $5 \%$ possui propriedade rural em São Paulo, no Norte Velho e, em parte, também no Norte Novo. Este grupo permaneceu domiciliado nas cidades ou, na sua maioria, na antiga propriedade. Por outro lado, mais do que três quartos dos atuais proprietários rurais, no exemplo de Umuarama, são antigos empreiteiros, meeiros, pequenos arrendatários, ou também trabalhadores rurais.

O Mapa 23 mostra que, na compra de terra nas proximidades de Umuarama por novos colonos provenientes de São Paulo (e em número inferior, também de Minas Gerais), esses colonos se estabeleceram em associações de turmas próximas uma das outras. Isso acontecia seja por causa do espírito de comunidade tradicional proveniente da região de emigração, seja por causa da mesma origem étnica (sobretudo italiana). A associação de vizinhança ganhou um significado bastante especial na fronteira de colonização.

Apesar de a gleba Jacaratiá (localizada nos atuais distritos Cedro e Perobal, do Município de Umuarama) estar localizada adiante em direção sudoeste da região de cultivo de café, a influência da migração provinda dos estados do Sul - Santa Catarina e Rio Grande do Sul - é extremamente pequena, com apenas $5 \%$ de proprietários rurais.

Entre os arrendatários domina uma alta mobilidade. Enquanto os empreiteiros trabalham diretamente na frente pioneira e seguem no frontier avançado - depois do decorrer de 4 a 6 anos, a depender do contrato - para que lá iniciem novamente a plantação de café, os arrendatários parceiros, ou também os colonos sucessores de empreiteiros estão em serviço, porém sob outra base contratual e função. A mobilidade espacial dos arrendatários é também direcionada para regiões recém colonizadas cujo solo ainda apresenta alta fertilidade. A duração das relações de arrendamento chegam, em geral, a 1 ou até 2 anos. Empreiteiros e meeiros são uma 'classe especialista' no plantio de café.

É certo que também muitos dos atuais trabalhadores rurais (colonos) se ocupam permanentemente no plantio de café, mas eles também mudam para outras ocupações facilmente. ${ }^{209}$ As regiões principais de procedência dos trabalhadores rurais - segundo a cidade natal ou a procedência dos pais - são os estados do Nordeste do Brasil e Minas Gerais. Em São Paulo, primeiramente tratou-se de familiarizar sobretudo os nordestinos com o plantio de café. O Paraná teve a grande vantagem de receber uma classe de trabalhadores rurais 'instruídos'. Em grande medida, nordestinos e mineiros são, como trabalhadores rurais, os sucessores dos descendentes de trabalhadores rurais italianos em São Paulo, os quais, na estrutura social rural do Norte do Paraná, ascenderam a arrendatários, empreiteiros ou pequenos proprietários rurais.

Primeiramente duas entrevistas apresentam as principais tendências no Município de Rolândia e de Apucarana, respectivamente:

208 No Mapa 23, os lotes de terra designados como ‘sem título' (41\%) estão na posse de sitiantes, que, até então, em confiança da segurança jurídica das propriedades do CMNP, ainda não buscaram a certidão de registro lavrada em cartório elaborada por uma taxa baixa.

209 A procura pelas melhores possibilidades de ganho leva frequentemente os trababalhadores à troca de um trabalho rural por outras ocupações urbanas. O alto grau de mobilidade profissional não é de forma alguma um sinal de insatisfação constante ou troca profissional forçada, mas muitas vezes o desejo de ascensão social. Nas marchas profissionais se reflete a situação instável da economia cafeeira, que leva a demissões temporárias. 
Tabela 14: Procedência dos colonos (segundo cidade natal/estado) de duas fazendas em Rolândia e Apucarana ${ }^{210}$

(parcela em \%)

\begin{tabular}{|c|c|c|}
\hline & \multirow[b]{2}{*}{ Rolândia } & \multirow[b]{2}{*}{ Apucarana } \\
\hline & & \\
\hline São Paulo & 23 & 28 \\
\hline Minas Gerais & 27 & 35 \\
\hline Nordeste & $\underline{44}$ & $\underline{19}$ \\
\hline Bahia & 16 & 8 \\
\hline Pernambuco & 11 & 2 \\
\hline Alagoas & 9 & 3 \\
\hline Sergipe & 3 & 2 \\
\hline Ceará & 4 & 2 \\
\hline Outros estados do NE & 1 & 2 \\
\hline Paraná & 2 & 16 \\
\hline Rio de Janeiro & 1 & 2 \\
\hline Outros estados & 2 & - \\
\hline \multirow[t]{2}{*}{ Estrangeiros } & 1 & - \\
\hline & 100 & 100 \\
\hline
\end{tabular}

Fonte: Entrevistas próprias do Autor (1970).

A alta porcentagem de trabalhadores rurais procedentes do Nordeste, no exemplo de Rolândia (44\%), corresponde à média geral do final dos anos 1950. ${ }^{211}$ Para evitar a alta flutuação desses colonos, muitos empreendimentos de médio e grande porte dão preferência, no processo de aumento de áreas de pastagem, aos trabalhadores de Minas Gerais, sobretudo porque eles em geral têm mais experiência também com os trabalhos que têm a ver com criação de bovinos. A porcentagem relativamente alta dos trabalhadores paranaenses no exemplo de Apucarana indica a contratação crescente de diaristas jovens que se estabeleceram, na maioria das vezes, em áreas periféricas dos centros urbanos do município.

Dos colonos naturais de São Paulo (23 a 28\%) em ambos os casos pesquisados, apenas $4 \%$ eram de ascendência italiana, um exemplo de que esse grupo étnico, pertence agora a outra classe social.

Para uma grande parcela de colonos provindos do Nordeste e de Minas Gerais, a colocação com contrato significa uma melhora significativa (plantações paralelas, moradia) em contraposição às ocupações que lhes eram dadas como trabalhadores migrantes.

É especialmente difícil fornecer indicações seguras sobre os trabalhadores migrantes. Quanto ao exemplo dos trabalhadores da usina de açúcar em Porecatu, deve-se fazer uma análise comparativa da procedência dos trabalhadores migrantes com trabalhadores rurais e de fábricas e funcionários da empresa.

Com relação aos trabalhadores migrantes, a parcela de nordestinos, com $46 \%$, é especialmente alta e o número dos que provêm de Minas Gerais, sobretudo os da parte norte e leste do Estado, é igualmente considerável. Uma vez que o conglomerado pertencente ao grupo de Lunardelli em Porecatu opera, para além do cultivo de cana-de-açúcar, plantações extensas de cultivo de café, há, entre junho e setembro, certos problemas de organização devido à sobreposição de períodos de colheita. Quanto às colheitas de cana-de-açúcar, prefere-se os nordestinos, que já trabalharam nas colheitas de cana-de-açúcar na região costeira de suas terras natais. O mesmo vale para os trabalhadores na usina de açúcar. A procedência dos trabalhadores rurais no cultivo de café oferece o já conhecido quadro da alta parcela dos paulistanos e mineiros.

210 Fazenda Conquista/Município de Rolândia: 167 fichas de trabalho entre os anos 1958 e 1961; Fazenda Ubatuba, Sta. Veronica, Sta. Helena/Município de Apucarana: 227 fichas de trabalho entre os anos 1968 e 1970. - Ver também o Mapa 11.

211 Duração média do contrato: 1,4 anos; número de pessoas por família de trabalhadores rurais: 5,7; idade do chefe de família: média de 37 anos. 
Tabela 15: Procedência de trabalhadores migrantes, trabalhadores rurais, trabalhadores de fábricas e funcionários da Usina Central Porecatu ${ }^{212}$ (parcela em \%)

\begin{tabular}{|c|c|c|c|c|c|}
\hline & \multirow[b]{2}{*}{$\begin{array}{l}\text { Trabalhadores } \\
\text { migrantes (sobre- } \\
\text { tudo no plantio de } \\
\text { cana-de-açúcar) }\end{array}$} & \\
\hline & & $\begin{array}{l}\text { Trabalhadores } \\
\text { rurais (café) }\end{array}$ & $\begin{array}{l}\text { Trabalhadores (da } \\
\text { usina de açúcar) }\end{array}$ & $\begin{array}{l}\text { Funcionários de } \\
\text { escritórios, oficinas } \\
\text { e armazéns }{ }^{213}\end{array}$ & Total \\
\hline São Paulo & 14 & 34 & 18 & 40 & 25 \\
\hline Minas Gerais & 35 & 32 & 17 & 12 & 26 \\
\hline Nordeste & $\underline{46}$ & $\underline{25}$ & $\underline{56}$ & $\underline{31}$ & $\underline{40}$ \\
\hline Bahia & 13 & 12 & 17 & 8 & 12 \\
\hline Pernambuco & 12 & 5 & 17 & 11 & 11 \\
\hline Alagoas & 9 & 3 & 6 & 4 & 6 \\
\hline Sergipe & 7 & 2 & 7 & 5 & 5 \\
\hline Ceará & 3 & 2 & 3 & 1 & 3 \\
\hline Outros estados do NE & 2 & 1 & 6 & 2 & 3 \\
\hline Paraná & 4 & 6 & 7 & 14 & 7 \\
\hline \multirow[t]{2}{*}{ Estados restantes } & 1 & 3 & 2 & 3 & 2 \\
\hline & $\begin{array}{c}100 \\
(1011)\end{array}$ & $\begin{array}{c}100 \\
(504)\end{array}$ & $\begin{array}{c}100 \\
(322)\end{array}$ & $\begin{array}{c}100 \\
(612)\end{array}$ & $\begin{array}{c}100 \\
(2449)\end{array}$ \\
\hline
\end{tabular}

Fonte: Entrevistas próprias do Autor (1970).

A mobilidade social e espacial específica segundo grupos e classes no Norte do Paraná será demonstrada de maneira resumida na Figura 4, a partir de grupos étnico-sociais petencentes a três classes sociais diferentes:

a) O primeiro grupo compreende os proprietários de plantação de café em São Paulo, em grande medida luso-brasileiros. Sua amplitude de reação ${ }^{214}$ no âmbito da expansão de café no Norte do Paraná decresce fortemente de leste para oeste. Enquanto o desenvolvimento da região de terra roxa do Norte Velho ainda é atribuído quase que totalmente a esse grupo, ele possui também algum significado no Norte Novo, sob parâmetros modificados de propriedade numa fase tardia, depois de 1930. Nas zonas pioneiras do Oeste, porém, sua influência direta se deu de modo reduzido.

b) Quanto ao segundo grupo, trata-se dos trabalhadores descendentes de italianos que, na segunda fase do século passado, formaram, como sucessores dos escravos em São Paulo, uma nova classe de trabalhadores de plantação. Seus filhos e netos, que em São Paulo eram ainda quase que exclusivamente trabalhadores rurais e arrendatários, demonstraram uma mobilidade social surpreendente, ao lado da mobilidade espacial, passando pelas zonas pioneiras do oeste paulista e do Norte Velho desde 1930 e, sobretudo desde o fim da Segunda Guerra, em todo Norte Novo e Norte Novíssimo. Passando pelas fases intermediárias de arrendatário ou empreiteiro, eles ascenderam, no Norte Novíssimo, a uma classe ativa de proprietários rurais autonômos.

c) Em contrapartida a esse forte componente de mobilidade social, a classe de trabalhadores migrantes mostra uma mobilidade predominantemente espacial. Esse grupo compõe-se de uma alta porcentagem de migrantes provindos dos Estados do Nordeste e de Minas Gerais. Também os trabalhadores rurais dessa procedência, empregados com contrato, mostram somente pouca mobilidade social.

212 Avaliação de fichas empresariais de 2.449 empregados, feita pelo autor. Trabalhadores migrantes em Porecatu: colheita de cana-de-açúcar em meados de maio a novembro e colheita de café de junho a setembro. Em São Paulo: colheita de algodão entre março e maio.

213 Para isso, comparar estrutura de procedência semelhante quanto à entrevista a trabalhadores industriais em Londrina (círculo interno) apresentada no Mapa 11, que, em 1970, foi realizada pelo autor, em Londrina com fins comparativos. Aqui também agradecemos o apoio amigável de V. Frech (Londrina).

214 Comparar com a concepção de amplitude de reação [Reaktionsweite] típica de grupo no estudo de Ruppert (1968). 
Figura 4: Mobilidade social e espacial específica segundo grupos e classes no cultivo de café no Norte do Paraná

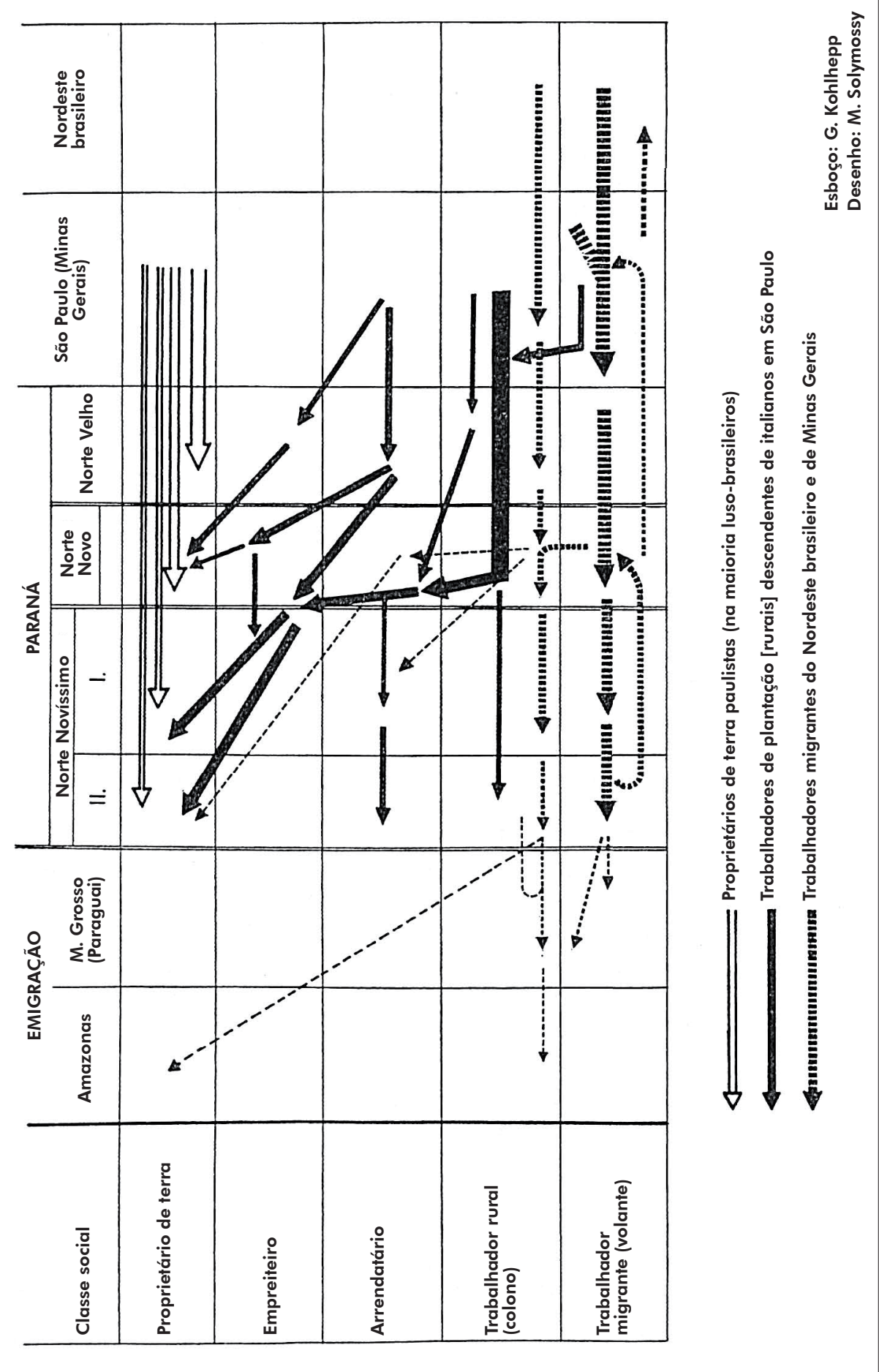

Fonte: Entrevistas e levantamentos do Autor, 1970. 
Cada uma das regiões são estações de passagem dos trabalhadores migrantes na sua busca constante por trabalho nos períodos de colheita. Parcialmente também se formou, como foi mencionado acima, uma migração pendular recíproca entre Paraná e São Paulo. Com as recentes crises do café sucedeuse, em parte, uma migração contínua para o Mato Grosso e a região amazônica, com a construção da Rodovia Transamazônica.

Até o momento desta pesquisa, no início dos anos 1970, apenas um pequeno grupo de nordestinos conseguiu dar o salto para aquisição de uma propriedade rural nas zonas pioneiras do noroeste (ver Figura 4). Na região de Porto Rico às margens do rio Paraná - explorada no começo dos anos 1950 —, $60 \%$ dos compradores de pequenas porções de terras, entre 2,5 e 35 ha, eram, no entanto, nordestinos que vieram, em grande medida, da região entre Mandaguari e Paranavaí, onde haviam trabalhado como colonos (PETRONE, 1957, p. 85).

As migrações internas provenientes do Nordeste trouxeram anualmente, nos anos 1950, mais de 500 mil pessoas para o sul. Secas catastróficas no sertão fizeram com que centenas de milhares de pessoas migrassem do Ceará, do interior do Rio Grande do Norte, Paraíba, Pernambuco, Alagoas, Sergipe e Bahia, passando pelos centros regionais urbanos, em direção às grandes cidades na região costeira, onde, porém, também não havia possibilidade alguma de trabalho (PFEIFER, 1956; TORRES, 1957). A principal onda migratória veio para o sul ou através da rodovia Salvador-Rio de Janeiro ou através da Ferrovia Central Monte Azul-São Paulo. Caminhões eram carregados frequentemente com mais de 70 pessoas, amontoadas em bancos de madeira, e eram designados de modo macabro como 'pau de arara'. Depois de muitos dias de viagem, chegavam às metrópoles do Rio ou de São Paulo ou em parte também direto para as regiões de plantio de café, onde, por conta da escassez de mão de obra, se pagava ao motorista do caminhão uma quantia para cada cabeça de trabalhador rural.

Por conta da crescente saturação de necessidade de mão de obra por volta do final do boom do café, a migração desordenada de nordestinos ocasionou grandes problemas no Norte do Paraná. Sobretudo o costume de autoridades da polícia local de entregar passagens de trem gratuitas 'até a última estação' à grande quantidade de pessoas desempregadas e esfomeadas no Nordeste, levou essas 'últimas estações' - os pontos finais da linha de trem no Norte do Paraná - a situações caóticas. Em Doutor Camargo, estação final a oeste de Maringá, centenas e milhares de pessoas chegavam em uma região que ficava muito atrás do frontier de meados dos anos 1950 e em cujas imediações predominavam, em sua maioria, pequenas e médias propriedades sem grandes necessidades de mão de obra. Junto ao problema de alimentação e sustento dos membros da família ${ }^{215}$ dos agora inúmeros nordestinos recém-chegados, o problema da obtenção de trabalho permaneceu sem solução.

Enquanto os baianos, em geral, mostravam um alto grau de estabilidade e se estabeleciam no Paraná, cerca de apenas $20 \%$ dos migrantes pernambucanos permaneceram. Depois do final do período de seca no Nordeste, a maioria retornou para lá.

\section{d) A mobilidade social dirigida dos colonos japoneses}

A observação do decurso dos processos de mobilidade espacial e social no Norte do Paraná leva a uma forma especial da mobilidade social dos imigrantes japoneses e de seus descendentes que se revela de modo "dirigido".

Para esclarecer o pano de fundo socioeconômico das atividades japonesas no Brasil, cabe fazer um breve relato.

A emigração do Japão, depois das restrições imigratórias dos Estados Unidos, dirigiu-se para a América do Sul, onde o Brasil, desde 1908 e, em maior medida, desde 1912, dirigiu a acolhida aos imigrantes japoneses. O objetivo brasileiro de ganhar trabalhadores assalariados para as plantações de café de São Paulo determinou o destino da primeira fase de imigração japonesa. Os imigrantes foram trazidos principalmente para a região de Mogiana.

O desconforto dos japoneses a respeito da função que foi prevista para eles e uma alta mobilidade espacial desse grupo - devido às más condições de vida nas fazendas de café - levaram à suspensão do subsídio dos custos de viagem pelo governo paulista, o que quase acabou com a imigração japonesa no começo dos anos 1920. A segunda fase da imigração japonesa para o Brasil começou com a intervenção do governo japonês, que assumiu os custos de passagem. O governo contribuiu não apenas para a fundação

215 Em meados dos anos 50, a zona pioneira apresenta ainda o típico excedente humano: 63\% dos migrantes eram homens, $21 \%$ mulheres e 16\% crianças (DIÉGUES, 1959, p. 118). 
de organizações de imigração, mas também providenciou a criação da fundação Brazil Takushoku Kumiai (Sociedade de desenvolvimento brasileiro) no Brasil. Devido à restrição da emigração italiana em 1927, a imigração japonesa articulada para o Brasil vivenciou o seu auge entre os anos de 1926 e 1935 com 133 mil pessoas.

Nesta fase, os emigrantes alistados no Japão foram cuidadosamente escolhidos e preparados para sua futura ocupação agrícola no Brasil. A maioria dos emigrantes foi para o Sudeste brasileiro, onde sobretudo a comunidade Kaigai Kogyo Kaisha era ativa (PELZER, 1937, p. 176ss.). O desenvolvimento florescente da imigração e da atividade colonizadora japonesa foi interrompida em 1934 pela nova constituição brasileira, que, como etapa preliminar da nacionalização, fixou a cota de imigração para cada país em $2 \%$ do número de imigrantes dos últimos 50 anos. Para o Japão, isso significou 3.480 imigrantes por ano. Nessa época, $40 \%$ dos imigrantes japoneses eram colonos nas plantações de café, $30 \%$ pequenos arrendatários e 30\% atuavam como colonos autônomos. (BOWMAN, 1937, p. 339)

Uma grande parte dos trabalhadores rurais japoneses emigrou e, depois do cumprimento de 1, 4 ou 6 anos de contrato nas plantações de café, começou como arrendatários ou, com reservas de dinheiro correspondentes, como proprietários de terra independentes em terras de comunidades japonesas de colonização (sobretudo na região costeira paulista, em torno de Iguape e no Vale do Ribeira, próximo a Registro) ou nas zonas pioneiras do noroeste de São Paulo. A colonização dessa zona era baseada especialmente no rendimento dos japoneses, que se estabeleceram como pequenos proprietários rurais e, nos anos anteriores à crise econômica mundial, trabalharam sobretudo no cultivo de café (MONBEIG, 1937 e 1952). A crise do café também ocasionou, entre os colonos japoneses, uma forte mobilidade espacial, concentrando-se, em parte, na região em torno da grande São Paulo, onde os japoneses obtiveram grande sucesso com o cultivo de legumes.

Na região da Alta Paulista e da Alta Sorocabana, sobretudo depois da crise econômica mundial, instaurou-se um boom do plantio de algodão, que, levado quase sempre por arrendatários e parceiros japoneses, trouxe uma nova orientação econômica para as zonas de expansão do oeste de São Paulo. O recuo do plantio de algodão, devido à exaustão dos solos arenosos, foi compensado pelos japoneses através da reestruturação para a criação de aves. A produção de ovos tornou-se a nova concentração econômica (AUGELLI, 1958a, segundo exemplo da colônia japonesa de Bastos, na região da Alta Paulista), mas não pôde evitar a emigração.

Além do forte fluxo de japoneses para a grande São Paulo - que foi uma consequência da rápida expansão industrial, exercendo influências significativas na mobilidade social e consequentemente profissional dos emigrantes japoneses - , a mobilidade geográfica teve como objetivo as novas zonas pioneiras do norte e noroeste do Paraná. Lá, a leste do Rio Tibagi, no começo dos anos 1930 já havia surgido uma colonização japonesa significativa em torno de Assaí, que se tornou o centro do cultivo de algodão paranaense..$^{216}$

Enquanto a mobilidade vertical dos membros de grupos examinados até aqui se dava seletivamente e sob a peculiar situação socioeconômica das zonas pioneiras, oferecia-se agora aos colonos da segunda fase de imigração japonesa, já escolhidos no Japão, o apoio da organização japonesa de colonização.

$\mathrm{O}$ alto rendimento característico de trabalho dos pequenos agricultores japoneses foi valorizado através do trabalho da Cooperativa Agrícola Cotia, a maior cooperativa da América do Sul, fundada pelos japoneses em 1927. Consultoria agrícola, planejamento de plantio, concessão de crédito e comercialização bem organizada dos produtos agrários estão entre as realizações dessa sociedade, cujos membros são até hoje $90 \%$ japoneses ou brasileiros de ascendência japonesa (ANDO, 1961). A ascensão social para proprietário da própria terra, aspirada com vontade férrea depois dos anos de aprendizagem como trabalhadores assalariados ou pequenos arrendatários, deu-se praticamente segundo os planos da Cooperativa Central Cotia com a ajuda dos bons rendimentos advindos da venda de bens agrícolas, em razão do afastamento de intermediários (Foto 8).

A migração japonesa de São Paulo para o Norte Novo do Paraná começou em 1930, quando se instaurou a venda organizada de terras pela Cia. Terras Norte Paraná. Entre 1933 e 1941, os japoneses eram o terceiro grupo mais forte entre os compradores de terra da CTNP, depois dos brasileiros e dos italianos (Tabela 3). Em 1950, dos 65 mil estrangeiros domiciliados no Paraná, os japoneses eram o grupo

216 Sobre isso, de modo geral, entre outros, Câmara e Neiva (1941); Willems (1951); Monbeig (1952); Sasaki (1958); Dorneich (1960); Saito (1961); Smith (1953); e uma visão geral da bibliografia de Harms - Baltzer (1968a e 1968b). 
mais expressivo, com $23 \%$, cuja porcentagem na população total do estado, porém, correspondia apenas a $0,7 \%$.

Em 1958, dos quase 400 mil japoneses e brasileiros descendentes de japoneses que eram domiciliados no Brasil, 75\% viviam no estado de São Paulo e 18\% no Paraná (SAITO, 1961, p. 159) - os últimos, quase sem exceção, na parte norte do estado.

Apesar de os japoneses terem um papel relativamente pequeno no plantio de café do Norte Novo e do Norte Novíssimo do Paraná, eles deram um impulso decisivo para o caráter cooperativo na região, com a construção da filial regional da 'Cotia'.

No cultivo de café ameaçado pela geada no norte do Paraná, os colonos de ascendência japonesa deram inúmeros estímulos para vantajosas culturas sucessoras.

A consciência de grupo deles - mais no sentido de união do que na forma de separação nacionalista -, sua capacidade para trabalhar duro e de maneira concentrada, e um vivo senso para desenvolvimento econômico e mercantil vantajoso produziram uma mobilidade social exemplar, cuja realização, através de diligências flanqueadas das sociedades japonesas de colonização e da infraestrutura comercial organizada cooperativamente, foi promovida e guiada conforme previsto.

\section{e) Mobilidade espacial: o exemplo dos cafeicultores alemães de Rolândia}

Para discorrer sobre os cafeicultores alemães ou de ascendência alemã em Rolândia (Norte Novo), é preciso antes atentar brevemente para a mobilidade espacial desses proprietários de empreendimentos de médio porte, no contexto de aquisição de terras para o cultivo de café. ${ }^{217}$

Para tanto, pode-se distinguir quatro grupos, cujas atividades, com diferentes motivações, concentram-se em duas fases de desenvolvimento e quatro áreas bastante distantes espacialmente:

1. No começo dos anos 1950, o objetivo do primeiro grupo era a expansão das plantações de café por meio da compra de terras no Oeste do Paraná. Sobretudo as condições extremamente favoráveis de crédito fundiário do Banco do Brasil, em Foz do Iguaçu, deram o impulso para isso.

Na região de Toledo (Vila Maripá), ao sul do rio Piquiri (a $360 \mathrm{~km}$ de Rolândia), havia ainda nessa época terras virgens, que foram loteadas por uma sociedade de colonização rio-grandense em porções de até 25 ha e compradas pelo grupo na forma de inúmeros lotes pequenos, com uma área total de muitos milhares de hectares. A fertilidade do solo era boa e a altitude de $550 \mathrm{~m}$ era propícia. Embora houvesse a consciência do perigo de geada, esperava-se poder reduzir esse fator de risco pelo aspecto da exposição das plantações no declive para norte ou pelo cultivo no espigão.

Após o começo do cultivo de café, os compradores de terra se transferiam mês a mês para a administração e para a supervisão das terras. As conexões de transporte e a aquisição de mão de obra foram extremamente difíceis. Por motivos de precaução, não se realizou nenhuma instalação fixa nos primeiros anos.

Depois de duas geadas leves e de uma boa colheita, com rápida recuperação dos cafeeiros, foram construídos terreiros e instalada uma máquina de descascar café. Depois, no entanto, as colheitas não puderam mais ser realizadas, em parte por causa das precipitações muito intensas e das geadas anuais, ocorridas extraordinariamente cedo. Assim, o experimento foi suspenso depois de quase uma década.

$2-3$. A partir dessas experiências, os outros grupos buscavam terras, que fossem baratas, livres de geada e propícias ao cultivo do café. O objetivo era, sobretudo, uma distribuição dos riscos no cultivo do café, por causa do perigo permanente de geada no Norte do Paraná.

Enquanto o grupo 2 migrava para o Espírito Santo, para as florestas tropicais inexploradas na fronteira sul do cultivo de cacau (1300 km de Rolândia em linha reta), o grupo 3, junto com um grande empresário industrial alemão, investia em plantações de café na região do Alto Jaurú, no noroeste do Mato Grosso, a uma distância de $1200 \mathrm{~km}$ de Rolândia ${ }^{218}$. Por causa das pragas na região próxima à costa, bem como dos problemas no controle do ciclo do trabalho, os proprietários residentes em Rolândia renunciaram às plantações de café no Espírito Santo. No Mato Grosso, as plantações dirigidas por paranaenses e por administradores alemães ainda existem neste início dos anos 1970, apesar das longas distâncias e péssimas conexões de transporte.

217 Informações gentilmente cedidas por diversos cidadãos de Rolândia, especialmente Sr. H. M. Bresslau.

218 Sobre o desenvolvimento na área de Alto Jaurú, cf. Pfeifer (1966a, p. 326ss.). 
4. O desenvolvimento mais recente mostra o desvio de um quarto grupo para o nordeste do Paraguai (região de Pedro Juan Caballero). Apesar de essa região distar algo como $500 \mathrm{~km}$ em linha reta, só se consegue chegar a ela percorrendo-se aprox. $900 \mathrm{~km}$ por estrada. O investimento em plantações de café em uma faixa de terra roxa do platô de Amambay, no Paraguai, tem motivos econômicos. O Paraguai não cobra impostos sobre o café, o que chega a render mais que o dobro para os plantadores de café na exportação, embora a condição de transporte seja bastante desfavorável. Por outro lado, o risco de geada é considerável. Apenas poucas plantações com localização favorável conseguiram escapar da geada em 1969.

A partir de uma visão geral ecológica e econômica, o empenho dos diferentes grupos de proprietários de plantações de café de Rolândia mostra que o cultivo de café já ocupa uma posição ideal e que a variedade de áreas de cultivo favoráveis já está esgotada. ${ }^{219}$

\section{f) Norte do Paraná: região-alvo da migração interna}

A caracterização do norte do Paraná como região-alvo para migração interna regional e suprarregional trouxe a essa região um benefício migratório significativo nas década de 1950 e 1960. Especialmente em comparação com as regiões mais importantes de cultivo de café do estado de São Paulo até o momento, a posição de exceção na evolução populacional absoluta e relativa é nítida (Mapa 24) ${ }^{220}$.

No Norte do Paraná, a distribuição da densidade populacional em 1960 (Mapa 25) mostra, de maneira impressionante, um direcionamento de oeste para sudoeste, o que se reflete na expansão do frontier do café. Na zona central, na região da divisora de águas entre Londrina e Maringá, os valores chegaram a mais de 75 habitantes por $\mathrm{km}^{2}$. Em alguns lugares na região de concentração urbana de colônias, os números sobem para mais de 100 por $\mathrm{km}^{2}$. Em direção ao sul, na zona periférica do cultivo de café com forte perigo de geada, ocorre uma queda rápida da densidade populacional na área de contato com a economia primitiva de sistema de rotação de terras na região de florestas de Araucária do Paraná central, em grande parte destruídas.

A propagação extensiva da densidade relativamente alta da população no Norte do estado se dá em clara oposição a ambas as zonas restantes de concentração relativa. No Sudoeste, os valores uniformes de densidade são um sinal do desenvolvimento da pequena propriedade rural pelos descendentes de colonos europeus do Rio Grande do Sul e Santa Catarina, na base da distribuição igualitária de propriedade. O Sudeste do Paraná, zona do primeiro e segundo planalto colonizada há tempos, aponta, ao contrário, para fortes fenômenos de densificação em torno de Curitiba e do centro urbano regional de Ponta Grossa. As regiões de pecuária extensiva dos Campos Gerais apresentam uma densidade populacional bastante pequena.

Entre 1950 e 1960, a intensidade dos processos de mobilidade da população rural, no Norte do Paraná, foi marcada pela fase final da expansão do cultivo de café brasileiro, que ocorre já há mais de um século. Essa década trouxe não apenas uma ampliação extraordinária das áreas de cultivo e um crescimento da produção de café, como também apresentou o apogeu de um fluxo de processo que se acelerou desde o fim da guerra, na velocidade da expansão do frontier do café (Mapa 19, 1950; Mapa 26, 1962-1964).

O Mapa 26 fornece uma impressão da propagação espacial de rendimentos relativamente altos 221 do cultivo de café no Norte do Paraná, sobretudo na comparação entre Paraná e São Paulo. A análise subsequente da economia agrária do Norte do Paraná posiciona-se sobretudo quanto à questão da predominância do cultivo de café e de sua estrutura interna.

219 Sobre a questão das áreas potenciais de cultivo de café, ver também Jonasson (1958).

220 O Norte Novíssimo, partes do Norte Novo (Maringá), o oeste e sudoeste do estado aparecem na estatística de 1950 e 1960 ainda como 'zona oeste' e são apresentados de maneira correspondente no Mapa 24.

221 Os valores de produção no Mapa 26 se relacionam a uma 'cálculo de densidade’ por hectare de área municipal e, por isso, aparecem desproporcionalmente baixos. No Paraná, o rendimento médio, em 1961, foi de 784kg por hectaare de área de cultivo de café. O rendimento trienal de 1962 a 1964 foi menor que a média correspondente de colheitas normais, por causa das geadas de 1962 e 1963. 


\section{POSIÇÃO E ANÁliSE DA ESTRUTURA DO CULTIVO DO CAFÉ NO NORTE DO PARANÁ NO INÍCIO DOS ANOS 1960}

O momento escolhido de 1960 e 1961 é caracterizado pelo fim do amplo ciclo migratório do cultivo de café. O frontier do café alcançou o rio Paraná; o cultivo de café ocupou espaços de apropriação qualitativamente graduados de acordo com fatores climáticos e pedológicos. Em seu desenvolvimento espacial e predominância econômica, o boom do café atingiu o seu apogeu no Norte do Paraná.

No ano de 1961, mais de 65\% das atividades agrícolas do Norte do Paraná implementou o cultivo de café a oeste do rio Tibagi. Com isso, negligenciam-se as áreas periféricas do Norte Novo e Novíssimo mais ao sul, nas quais se renunciou incisivamente à plantação de café por causa do perigo mais elevado de geada; assim, a porcentagem na área restante aumenta em $74 \%$.

O cultivo de café ocupa $71 \%$ da área total cultivada da zona analisada e $82 \%$ da terra cultivada dos empreendimentos para cultivo de café222. A área de cultivo de café no Norte Novo perfazia 685.000 ha e, no Norte Novíssimo, 718.000 ha. Somente essas regiões do Paraná possuem $24 \%$ da totalidade de cafeeiros no Brasil ${ }^{223}$ e quase $40 \%$ da produção de café do país.

Como então classificar o cultivo de café dentro da área total do empreendimento?

\section{a) O uso da terra no Norte Novo e no Norte Novíssimo}

Em termos de diferenciação regional, o estudo do uso da terra no Norte Novo e Novíssimo (Tabela 16, p. 106) evidencia uma predominância muito forte, até mesmo absoluta, da cultura permanente nas regiões de Londrina e sobretudo Maringá. A parte da cultura permanente na área das propriedades, ou seja, do cultivo de café, atinge o seu máximo com $61,4 \%$, na região em torno de Maringá, e diminui claramente nas áreas periféricas do sul (região de Apucarana e Campo Mourão). Lá, a parte da área para cultura temporária, sobretudo de alimentos de primeira necessidade, cresce nitidamente e supera a área para cultivo de café na região de Campo Mourão. Os pastos de desmatamento se desenvolveram, contudo a criação de gado encontra-se num estágio ainda inicial de desenvolvimento. Em todo o Norte Novíssimo (40\%), assim como ao sul do Norte Novo (Apucarana: 30\%), a porção de floresta na área dos estabelecimentos agrícolas era, em 1960, ainda considerável (ver Tabela 16).

Os estágios de desenvolvimento podem ser percebidos na porção da área das propriedades agrícolas dentro da área municipal, que perfaz quase $88 \%$, na região em torno de Londrina e mais de $75 \%$ no Norte Novo como um todo. Por volta de 1960, também o norte do Norte Novíssimo (Paranavaí) já havia sido apropriado em sua maior parte (área de atividade: $77 \%$ da área total), enquanto que na região de Umuarama a área dos estabelecimentos agrícolas ocupava somente algo mais que um terço da área total que, em sua maior parte, ainda era de florestas. No entanto, essa apropriação de terra tinha se realizado no decorrer de poucos anos.

A observação da porção da área de cultivo de café na terra cultivada em âmbito municipal (Mapa 27) acaba por mostrar a predominância, em grande medida absoluta, do cultivo de café, que compreende, por exemplo, na região de Maringá, em média $72 \%$ da área cultivada, e, em casos isolados, atinge mais de $80 \%$. Apenas nas áreas de cultivo mais ao sul, com grande risco de geadas, o café fica atrás de outros produtos agrícolas. De maneira geral, as áreas de pastagem, quase sem exceção artificiais, ocupam a segunda posição depois do café.

Em 1960, durante o auge do boom do café, esse modelo de cultivo não era de modo algum limitado à região dos solos férteis de terra roxa, mas se estendia também até a região dos solos arenosos do Oeste e Noroeste, como mostra o Mapa 27.

222 Dados numéricos segundo IBC-OEA (1964), recalculados para nível regional.

223 O total de cafeeiros na área em estudo perfazia 1,035 bilhões em 1961. 


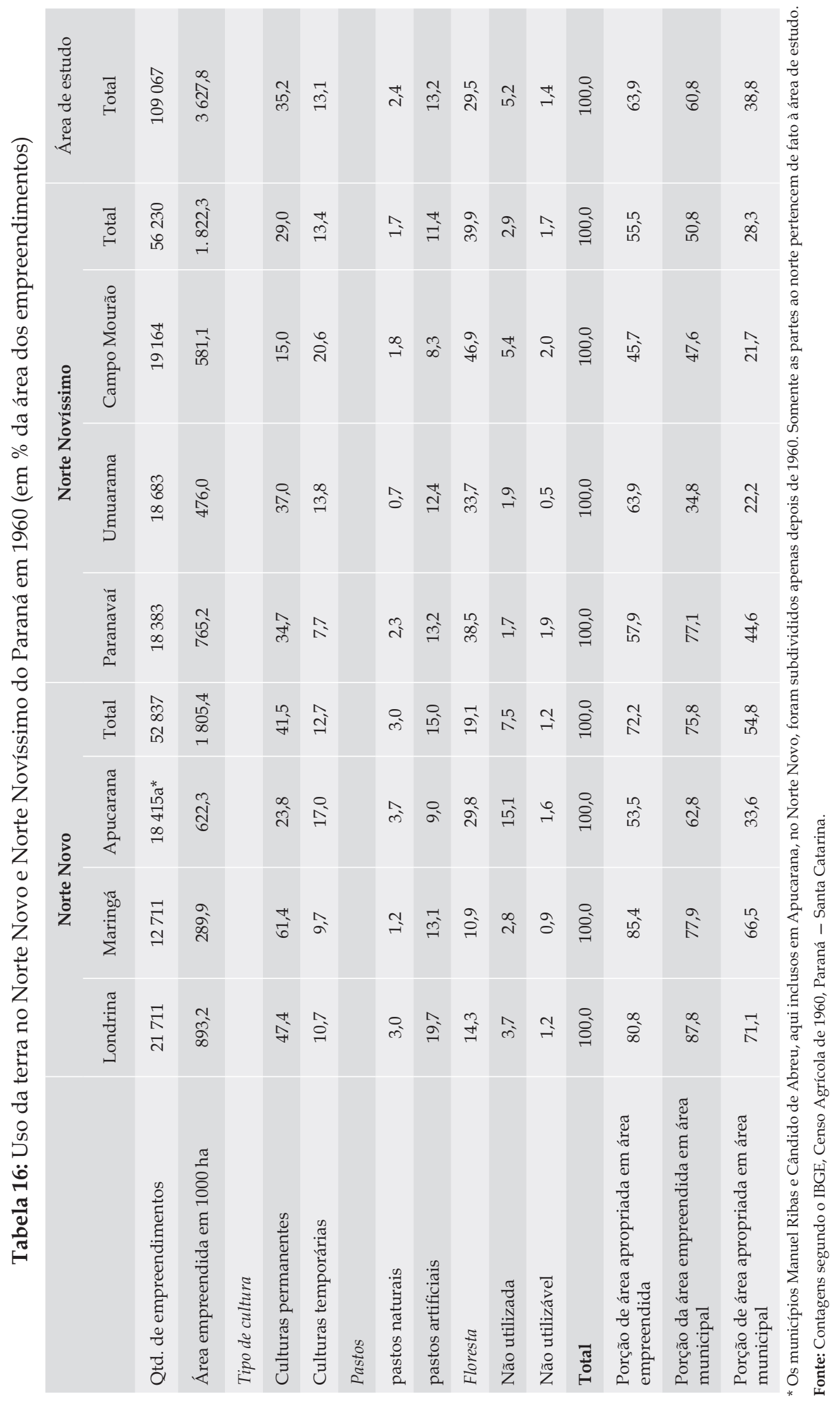




\section{b) Tamanho do empreendimento}

A diferenciação do tamanho dos empreendimentos agrícolas da área em estudo é apresentada na Tabela 17 para as regiões específicas do Norte Novo e Novíssimo.

A concentração das escalas de frequência de empreendimentos e de suas áreas mostra uma proeminência inequívoca dos empreendimentos entre 10 e 50 ha, que, na região de Maringá, são, por exemplo, $55 \%$ do número e $53 \%$ da área dos empreendimentos. A grande importância dos empreendimentos de pequeno e médio porte remonta sobretudo à distribuição de terra no contexto da colonização privada induzida no Norte do Paraná.

As porções correspondentes da área dos empreendimentos das classes de tamanho específicas na área de empreendimento total (Mapa 28) mostram um modelo de distribuição característico e relativamente uniforme para partes vastas do Norte do Paraná, a oeste do Tibagi. A antiga área de colonização da CTNP se distingue claramente com uma porção de área predominante da pequena e média propriedade (até 50 ha). Em municípios como Terra Boa ou Jussara, as atividades de pequeno porte de até 20 ha ocupam, em parte, mais de $60 \%$ da área empreendida. Existem poucos empreendimentos com mais de 100 ha.

Apenas no norte e no sudeste da região de Londrina, no sul da região de Apucarana, assim como no Norte Novíssimo ao norte do rio Ivaí, os empreendimentos de grande porte ocupam uma posição significativa. As porções de área dos empreendimentos com mais de 500 ha ficam em Porecatu e Florestópolis (plantações de cana-de-açúcar e café do grupo Lunardelli), com $84 \%$ e $58 \%$ da área total, respectivamente, e, em Querência do Norte e Loanda, no rio Paraná, (pecuária) com $80 \%$ e $51 \% .{ }^{224} \mathrm{Na}$ região de Paranavaí, empreendimentos desse porte exigem mais de um terço da área do empreendimento (Tabela 17).

\section{c) Análise da estrutura dos empreendimentos de cultivo de café}

Uma clara diferença vem à tona ao se comparar as dimensões de empreendimentos de plantio de café das regiões pesquisadas com outras regiões agrícolas do Brasil:

Em média, a área de empreendimento no Norte Novo comporta 49,7 ha, no Norte Novíssimo 69,5 ha, em Minas Gerais 76 ha e em São Paulo 115 ha. Porém, quando se compara cada área de plantio de café por empreendimento, então, as regiões paranaenses, com áreas entre 21,8 e 26,7 ha, são muito maiores que as áreas médias de plantação de café por empreendimento em Minas Gerais $(8,4$ ha) e São Paulo (16,2 ha), mesmo que as dimensões totais de área das últimas sejam maiores. ${ }^{225}$

No Norte do Paraná, segundo o número de cafeeiros, o conjunto de ordens de grandeza de empreendimentos de plantio de café mostra o claro domínio dos pequenos e médios empreendimentos. Como critério de delimitação para empreendimentos pequenos, médios e de grande porte no plantio de café, entre outros, tem-se a existência de instalações para secagem, preparação, classificação etc., e, quanto ao funcionamento, começa-se vagarosamente a partir de 16.000 árvores, aumenta-se significativamente a partir de $64.000^{226}$ e torna-se regra de instalação a partir de 100.000 a 120.000 árvores.

224 Cálculos segundo IBGE, Censo Agrícola de 1960. Paraná - Santa Catarina.

225 Segundo informações no IBC-OEA (1964) e UNITED NATIONS - ECLA/FAO (1960). (Para São Paulo 1958, Paraná e Minas Gerais 1961).

226 Segundo o esquema classificatório do Instituto Brasileiro do Café no IBC-OEA (1964). 


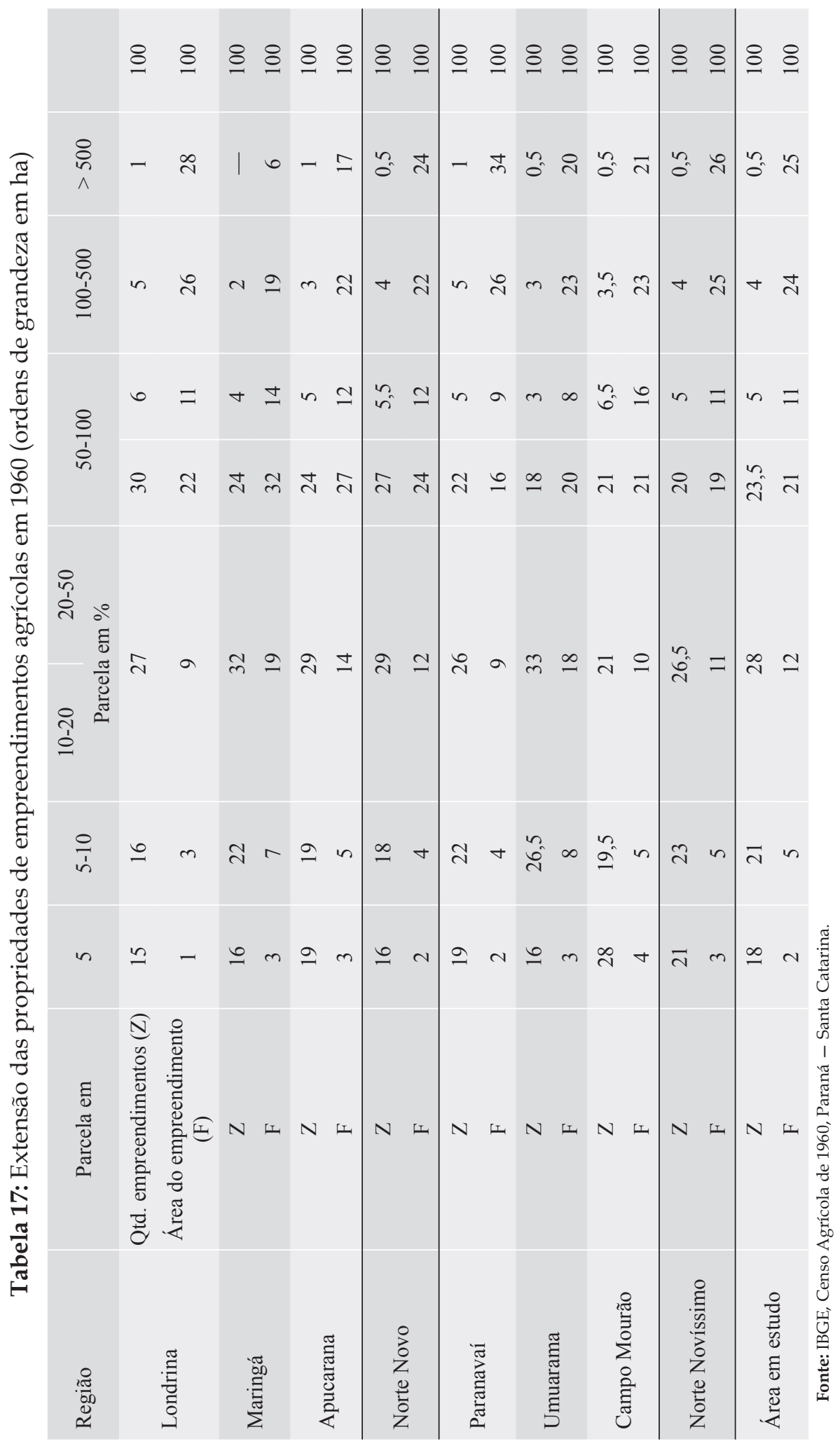


Tabela 18: Ordens de grandeza dos empreendimentos rurais com plantio de café em 1961

\begin{tabular}{|c|c|c|c|}
\hline \multirow{2}{*}{ (em 1000 cafeeiros) } & & Qtd. empreendimentos & Qtd. cafeeiros \\
\hline & & \multicolumn{2}{|c|}{ Parcela em $\%$} \\
\hline$<1$ & $\begin{array}{l}\text { Menor empreend. } \\
\text { (chácara) }\end{array}$ & 4,4 & 0,2 \\
\hline $\begin{array}{c}1-4 \\
4-8 \\
8-16\end{array}$ & $\begin{array}{l}\text { Pequeno empreend. } \\
\text { (sítio) }\end{array}$ & $\begin{array}{l}11,1 \\
31,3 \\
26,5\end{array}$ & $\begin{array}{c}1,5 \\
10,3 \\
16,6\end{array}$ \\
\hline $\begin{array}{l}16-32 \\
36-64\end{array}$ & $\begin{array}{l}\text { Empreend. médio } \\
\text { (sítio) }\end{array}$ & $\begin{array}{c}14,8 \\
7,6\end{array}$ & $\begin{array}{l}17,8 \\
19,2\end{array}$ \\
\hline \multirow[t]{2}{*}{$\begin{array}{c}64-128 \\
128-256 \\
256-1.024 \\
>1.024\end{array}$} & $\begin{array}{l}\text { Grande empreend. } \\
\text { (fazenda) }\end{array}$ & $\begin{array}{l}2,8 \\
1,1 \\
0,4\end{array}$ & $\begin{array}{c}13,5 \\
10,5 \\
8,4 \\
2,0\end{array}$ \\
\hline & & 100,0 & 100,0 \\
\hline
\end{tabular}

Fonte: IBC-OEA (1964).

Enquanto $73 \%$ dos empreendimentos com parcos $29 \%$ de cafeeiros têm menos que 16.000 cafeeiros, $22 \%$ pertencem, com $37 \%$ do estoque, ao grupo das propriedades de médio porte, que ainda são chamadas igualmente de sítio; com relação às maiores, em parte, já são chamadas de 'fazenda'.

Em 1961, apenas 4,3\% dos empreendimentos com 34\% do número total de cafeeiros ${ }^{227}$ podiam ser considerados empreendimentos de grande porte ('fazendas').

Isso levanta a questão quanto a tratar-se realmente de plantations nesses empreendimentos de grande porte. O conceito de plantation na forma clássica de Waibel (1933) e na tipologia de Gerling (1954) deve ser ampliado ao aspecto social e econômico e compreendido "somente como conceito geral abrangentes". 228

Precisamente com relação às plantações de café no Brasil, não se trata de uma forma tradicional de serviço 'colonial', mas sim de procedência 'nacional', no que diz respeito aos proprietários de terra, empreendedores ou administradores, e, em parte, também à organização da comercialização e da exportação. Na estrutura social daqueles que se ocupam das plantações de café, desenvolvem-se formas especiais (por exemplo, empreiteiro) (ver Cap. IV, 2) que certamente mostram traços bastante distintivos na fase inicial. Da mesma forma, o trabalho rural reestruturado através da legislação agrária não pode ser visto como um grupo social uniforme, como se tentou apresentar nas ponderações do capítulo anterior.

Os critérios das dimensões dos empreendimentos e a expansão territorial de culturas específicas de plantio seguiram orientados para a monocultura, bem como a grande necessidade de mão de obra e a orientação do mercado mundial, 229 e também altos investimentos capitalizados para instalações, necessários para o processo de preparação e comercialização (terreiro, instalações de secagem; máquina de beneficiamento, máquina descascadora; separadora; ensacamento de grãos, meios de transporte etc.)

Partindo-se da dimensão do empreendimento, o valor limite mais baixo citado para empreendimentos de grande porte (64 mil cafeeiros) corresponde, então, a uma área de plantio de 88 ha. ${ }^{230}$ Segundo a tabela 19 abaixo, a parcela de área de plantio de café, na área de empreendimento de grande porte de 64 a 128 mil, compreende $33,8 \%$, de modo que o valor limite da área do empreendimento compreende, quanto à ordem de grande porte de 64.000 árvores, em torno de 260 ha.

Essa área de empreendimento e o tamanho da área de plantio do cash crop - cuja parcela na área do empreendimento é relativamente baixa, conforme relevo e expansão da área nos vales com perigo

227 Esses valores concernem a todo o Norte do Paraná, também o Norte Velho, e não puderam ser classificados por meio das estatísticas existentes. O número dos empreendimentos de grande porte e a parcela correspondente de cafeeiros devem ser consideravelmente menores no Norte Novo e Novíssimo.

228 Manshard (1968, p. 140); sobre isso, ver Courtenay (1969) e em Kostrowicki e Tyskiewicz (1970, p. 91ss.).

229 O cultivo de café de empreendimentos agrícolas no Norte do Paraná sustentados por uma ampla classe média também é orientado pelo mercado mundial.

230 Em uma densidade de plantação de 730 cafeeiros/ha, ou seja, 13,7 $\mathrm{m}^{2}$ para cada árvore, o que no Paraná corresponde, em média, a empreendimentos com mais de 64.000 cafeeiros (IBC - OEA, 1964, p. 123). 
de geadas no caso especial do Paraná - formam, juntamente com a acumulação já mencionada de instalações técnicas e os investimentos capitalizados necessários para isso, um limite mais baixo para a designação de plantations ${ }^{231}$.

A sensibilidade conjuntural do café como produto e a situação especial do risco de geada no Paraná refletem-se em uma tendência crescente de diversificação de plantações, assim como a criação de bovinos ${ }^{232}$ que, no entanto, se difere ainda fortemente dos empreendimentos paulistas de café e bovinos ou café e lavouras ${ }^{233}$.

Tabela 19: Parcela de cultivo de café em área de empreendimento e área de cultivo dentro de cada ordem de grandeza dos empreendimentos

\begin{tabular}{|c|c|c|c|}
\hline Em 1000 cafeeiros & $\begin{array}{c}\text { Área de empreendimento } \\
\text { em } 1.000 \text { ha }\end{array}$ & $\begin{array}{c}\text { Parcela da área de cultivo de café } \\
\text { na área de empreendimento }(\%)\end{array}$ & $\begin{array}{c}\text { Parcela da } \\
\text { área de cultivo de café } \\
\text { em terreno agrícola }(\%)\end{array}$ \\
\hline$<1$ & 26,6 & 22,2 & 69,4 \\
\hline $1-4$ & 234,6 & 15,8 & 43,9 \\
\hline $4-16$ & 194,0 & 39,4 & 76,2 \\
\hline $16-32$ & 301,2 & 41,5 & 82,3 \\
\hline $12-64$ & 310,4 & 50,0 & 83,6 \\
\hline $256-128$ & 347,7 & 46,0 & 88,6 \\
\hline 1.024 & 231,1 & 33,8 & 83,7 \\
\hline
\end{tabular}

Fonte: IBC - OEA (1964).

Nos empreendimentos de médio porte (com entre 16 e 32 mil cafeeiros), a parcela de área de cultivo de café na área de empreendimento está com 50\% no máximo. Mesmo que dos altos valores da parcela de plantações de café no terreno agrícola se possa deduzir o domínio da monocultura do plantio de café, deve-se aqui enfatizar a importância das plantações paralelas. Essa plantações paralelas, no entanto, não se limitam no Paraná de modo algum apenas às partes próximas das casas, mas formam, em grande medida, uma verdadeira cultura mista, ${ }^{234}$ que não se limita somente aos primeiros quatro anos até o começo da primeira colheita das plantações de café, diferentemente das regiões de plantio de café restantes no Brasil. No total, mais de $60 \%$ das áreas de cultivo de café apresentam plantações paralelas de milho ( $44 \%)$, feijão $(27 \%)$, arroz ( $26 \%$ ) etc., de modo que os valores em pequenos empreendimentos e de médio e grande porte têm diferenças irrelevantes $(54-65 \%){ }^{235}$

231 Já apontou-se anteriormente que uma autonomia total no beneficiamento e na comercialização no Norte do Paraná frequentemente só se alcança em empreendimentos com mais de 100.000 cafeeiros, que, em média, possuem por volta de 400 ha de área empreendida.

232 Em média, no ano de 1961, com relação aos empreendimentos que cultivam café do Norte do Paraná, 40\% da área empreendida estava com café plantado e $9 \%$ com plantio de frutas. $18 \%$ foram ocupados por pastagem, $3 \%$ por estradas, construções etc., $7 \%$ por capoeira, $19 \%$ por mata virgem. A parcela de reflorestamentos consiste em $0,3 \%$, e 3,4\% não foram utilizados (segundo IBC - OEA, 1964, p. 44).

233 Lá, são comuns valores menores ou pouco maiores que 20\% para áreas de plantio de café e o restante de 40 - 65\% para áreas de pastagem ou $40-50 \%$ para área de cultivo. Cf. United Nations (ECLA/FAO), 1960, 11 e exemplos utilizados em Blankenburg e Cremer (1967, 1 p. 191-192).

234 As declarações contrastivas de Manshard (1968, p. 144) não se aplicam no Paraná e, em São Paulo, somente em parte.

235 Apenas em pequenos empreendimentos de menos de mil árvores, são cultivados somente $27 \%$ da área de plantio com plantações paralelas (IBC - OEA, 1964, p. 118). 
As plantações paralelas ${ }^{236}$ são cash crop apenas para os empreiteiros, caso contrário elas servem quase que exclusivamente como abastecimento de alimentos básicos para trabalhadores rurais, parceiros etc.

De uma visão econômica, o café como cash crop tem uma posição monopolizadora. No começo dos anos 1960, 90\% dos rendimentos de pequenos e médios empreendimentos foi o café, e em empreendimentos de grande porte significou em média $70 \%$.

Tabela 20: Idade das plantações de café nas regiões de cultivo do Norte do Paraná em 1961

(Parcelas em \%)

\begin{tabular}{|c|c|c|c|c|c|}
\hline Idade em anos & Época de plantio & $\begin{array}{c}\text { Norte } \\
\text { Novíssimo }\end{array}$ & $\begin{array}{l}\text { Norte } \\
\text { Novo }\end{array}$ & $\begin{array}{l}\text { Norte } \\
\text { Velho }\end{array}$ & Total \\
\hline até 3 & $1959-61$ & 11,6 & 5,6 & 3,6 & 7,9 \\
\hline $4-6$ & $1956-58$ & 13,8 & 6,4 & 7,0 & 9,7 \\
\hline $7-12$ & $1950-55$ & 71,3 & 57,8 & 38,0 & 60,0 \\
\hline $13-20$ & $1942-49$ & $\begin{array}{l}\text { Sobretudo a partir de } \\
\text { 1947: } 3,3\end{array}$ & 26,4 & 26,2 & 16,1 \\
\hline $21-30$ & $1932-41$ & - & 3,5 & 17,2 & 4,6 \\
\hline$>30$ & antes de 1932 & - & 0,3 & 8,0 & 1,7 \\
\hline & & 100,0 & 100,0 & 100,0 & 100,0 \\
\hline \multicolumn{2}{|c|}{ cafeeiros em milhões } & 564,8 & 470,3 & 245,9 & $1.281,0$ \\
\hline \multicolumn{2}{|c|}{ Idade média em anos } & 8,1 & 11,3 & 15,7 & \\
\hline \multicolumn{6}{|c|}{ Estoque total segundo grupos de idade } \\
\hline até 3 & $1959-61$ & 64,7 & 26,4 & 8,9 & 100,0 \\
\hline $4-12$ & $1950-58$ & 53,7 & 33,9 & 12,4 & 100,0 \\
\hline $13-20$ & $1942-49$ & 9,0 & 59,9 & 31,1 & 100,0 \\
\hline$>20$ & antes de 1942 & -- & 22,5 & 77,5 & 100,0 \\
\hline
\end{tabular}

Fonte: IBC - OEA (1964).

Em 1961, no Norte Velho, nordeste do estado, mais do que 25\% dos cafeeiros existentes tinham acima de 20 anos (plantio anterior a 1942); no Norte Novo, por outro lado, menos de 4\%. Enquanto mais do que um quarto dos cafeeiros no Norte Velho e no Norte Novo foram plantados entre 1942 e 1949 (sobretudo depois de 1946), somente neste momento começou o plantio no recém-constituído Norte Novíssimo. A primeira metade dos anos 1950 trouxe o grande boom do café. Nas regiões jovens de colonização foi implementada muito mais do que a metade das plantações de café existentes; no Norte Novíssimo mais do que 70\% neste período de tempo de 5-6 anos (1950 até 1955), e se encontravam, no começo dos anos 1960, na melhor idade de produção (7-12 anos).

Em 1961, aproximadamente 12\% dos cafeeiros do Norte Novíssimo ainda não tinham chegado à idade de produção, outros $14 \%$ ainda se encontravam em estágio inicial. Esse fato fez com que a zona pioneira do noroeste esperasse por um próximo aumento considerável da produção.

O grave problema da produção excedente de café ocorreu não somente por conta da quantidade de cafeeiros em plena produção, mas sobretudo pelos altos rendimentos consequentes, que foram obtidos graças aos solos virgens do Norte do Paraná.

Em 1961, o rendimento médio no Norte Novo ascendeu a 1.309 kg para cada mil árvores, ou seja, 904 kg/ ha de área cultivada. São valores excepcionalmente altos, que mostram a fertilidade da terra roxa. ${ }^{237}$

236 Veja também Cap. VIII, 1a, Tabela 41 (p. 310, Anexo) e Mapas 36-38.

237 Ademais, cabe observar que as declarações do Instituto Brasileiro do Café consideram o número total de cafeeiros, ou seja, incluem também os que ainda não estão produzindo. Considerando apenas os cafeeiros com mais de 3 anos, os números de rendimento são aproximadamente 8-9\% mais altos. 
Apesar de os números de rendimento nos solos arenosos do Norte Novíssimo consistirem em $770 \mathrm{~kg} / 1.000$ árvores ou $609 \mathrm{~kg} / \mathrm{ha}$ - quase $50 \%$ mais baixos do que na região da terra roxa - , eles ainda superam amplamente - no estágio inicial de produção - os rendimentos das outras regiões brasileiras de cultivo: São Paulo (1958: 446 kg/ha), Minas Gerais (347 kg/ha) e Espírito Santo (307 kg/ha). Os números de rendimentos comparáveis com a Colômbia compreendem $523 \mathrm{~kg} / \mathrm{ha}$ em 1955/56 e, em 1954/55 em El Salvador, 659 kg/ha, e são também consideravelmente mais baixos do que os valores médios do Norte Novo e também abaixo da média de todo o Paraná (784 kg/ha). No Norte Novo, apenas $27 \%$ dos cafeeiros foram adubados ( $8 \%$ de adubo químico, $19 \%$ orgânico), no Norte Novíssimo até mesmo apenas $21 \%$ deles. ${ }^{238}$

\section{d) Formas de gestão de cultivo}

A análise da forma de gestão de cultivo das plantações de café mostra que $35 \%$ dos empreendimentos com plantio de café ( $27 \%$ dos cafeeiros) são geridos por parceiros (sobretudo meeiros), 33\% (13\%) pela família do proprietário, $11 \%$ (23\%) por colonos, $7 \%(10 \%)$ por diaristas, $6 \%$ por meeiros e proprietários, $1,5 \%$ por colonos e proprietários, $1,4 \%$ por empreiteiros ( $5 \%$ dos cafeeiros); o restante foi gerido por outras combinações (IBC-OEA, 1964, p. 66).

Com isso, a média do tamanho do empreendimento aumenta - dependendo da forma de gestão de cultivo - de 7.000 cafeeiros, com relação a empreendimentos geridos somente pelo proprietário, para mais de 13.000 quando geridos pelos parceiros; 38.000 quando geridos por colonos; e para 65.000 quando geridos pelos empreiteiros.

Segundo uma pesquisa por amostragem do IBC em 1961, as formas de gestão de cultivo e as classes de dimensões de empreendimentos com plantio de café estão correlacionadas da maneira como demonstrada na Tabela 21.

Tabela 21: Formas dominantes de gestão de cultivo no cultivo de café segundo a posição do gestor e ordens de grandeza dos empreendimentos

\begin{tabular}{|c|c|c|c|c|c|c|c|}
\hline \multirow[t]{2}{*}{ em 1000 cafeeiros } & proprietário & colono & parceiro & empreiteiro & diarista & outros & Total \\
\hline & \multicolumn{7}{|c|}{ Parcela em \% } \\
\hline$<1$ & 51 & 5 & 49 & & & & 100 \\
\hline $1-4$ & 63 & 5 & 32 & & & & 100 \\
\hline $4-8$ & 49 & 6 & 39 & 1 & 5 & & 100 \\
\hline $8-16$ & 31 & 11 & 44 & 2 & 11 & 1 & 100 \\
\hline $16-32$ & 19 & 16 & 50 & 6 & 9 & & 100 \\
\hline $32-64$ & 8 & 36 & 31 & 7 & 14 & 4 & 100 \\
\hline $64-128$ & 2 & 41 & 26 & 8 & 13 & 10 & 100 \\
\hline $128-256$ & 1 & 34 & 12 & 23 & 23 & 7 & 100 \\
\hline$>256$ & - & 56 & 5 & 7 & 31 & 1 & 100 \\
\hline
\end{tabular}

Fonte: IBC-OEA (1964); resumo generalizante.

A parcela de proprietários rurais entre os gestores se reduz rapidamente com o crescimento da dimensão do empreendimento. Empreendimentos de grande porte quase não são geridos pelo próprio proprietário, prevalece o absentismo [absentee-ownership]. Os parceiros também retrocedem com o aumento da dimensão do empreendimento. A tendência contrária observa-se com relação aos colonos e diaristas, cuja parcela aumenta com a dimensão do empreendimento. A forma de gestão de cultivo mostra, através dos empreiteiros, um aumento médio da propriedade de grande porte; apenas com relação a grandes plantações fortemente capitalizadas o empreiteiro tem uma importância menor, pois o

238 Adubos químicos são utilizados apenas em empreendimentos de grande porte. Com relação ao adubo orgânico predomina a palha de milho $(80 \%)$. 
administrador sediado trabalha preferencialmente com colonos contratados ou diaristas que não podem exigir parcela alguma da colheita de café. Dentro de cada ordem de grandeza dos empreendimentos, o proprietário é responsável pela gestão de até 8.000 cafeeiros, nos empreendimentos pequenos e médios (de 8 a 16 mil e de 16 a 32 mil, respectivamente) cabe ao parceiro essa responsabilidade, e, a partir dos empreendimentos de médio porte maiores, prevalece o colono na gestão do cultivo.

A alta parcela de parceiros (meeiros) evita, devido aos breves contratos de parceria - como já foi mencionado - uma gestão de cultivo conservadora e contínua no plantio de café. A economia de parceria é um dos principais motivos para a escassa difusão da adubação.

No que concerne ao estatuto jurídico de gestão de cultivo, há no nível do município dados do ano de 1960 somente para todos os empreendimentos agrícolas (Mapa 29). ${ }^{239}$

No total, predomina o número de empreendimentos geridos pelos proprietários no Norte Novo (62\%); na área central da antiga região de colonização da CTNP, predomina também sua parcela de área que alcança, em alguns municípios, valores entre 70 e $77 \%$. Aqui, representam exceção apenas terrenos de grande porte no norte, junto ao Rio Paranapanema, e no sul do Município de Londrina. Em 1960, $28 \%$ dos empreendimentos do Norte Novo foram geridos por arrendatários, dos quais $85 \%$ realizam os pagamentos com produtos.

Também no Norte Novíssimo prevalecem os empreendimentos dirigidos pelo proprietário rural e sua família (55\%). Contudo, sobretudo no Noroeste (região de Paranavaí), a parcela de área dos empreendimentos geridos pelo proprietário retrocede fortemente - como se pode depreender do Mapa 29. Lá, $50 \%$ da área do empreendimento - ou seja, grandes empreendimentos de médio e grande porte - é gerida pelo administrador. No Norte Novíssimo em 1960, a relação entre o pagamento em produtos e o pagamento em dinheiro em contratos de arredamento chega a 3:1.

A pouca influência dos ocupantes ativos sem título de propriedade é de especial importância para a estabilidade das relações legais de possse. Os ocupantes, em toda a região estudada, gerenciam apenas quase $2 \%$ dos 110 mil empreendimentos totais em cerca de 1,5\% da área. Essa porcentagem, para a zona pioneira brasileira, é extraordinariamente baixa e mostra o valor da colonização conduzida com atribuição impecável de título de propriedade. Isso vale para o Norte Novo desde o começo da colonização privada através da CTNP. Para o Norte Novíssimo, somente desde a regularização dos problemas legais de posse originados no âmbito da colonização estatal.

No final dos anos 1940 até o começo dos anos 1960, a análise global do desenvolvimento do plantio de café no Norte do Paraná mostra a construção de uma formação econômica ${ }^{240}$ que é determinada principalmente pelo plantio de café em sistemas empreendedores do campo. 284 mil famílias com 576 mil trabalhadores, ao todo 1,46 milhões de pessoas, foram domiciliadas em plantações de café ou se ocuparam das mesmas (IBC-OEA, 1964, p. 72-73).

O boom do café no Norte do Paraná, com a expansão extraordinariamente rápida das áreas de plantio e com os altos rendimentos em solos virgens, confrontou o Brasil em 1960 novamente com o problema da produção excessiva de café, que, três décadas antes, já tinha estremecido a economia do país.

A análise que se segue sobre a situação do mercado cafeeiro mostra as repercussões diretas das oscilações de preços sobre a atividade de plantio de café. Diante do pano de fundo da situação econômica e política do café de países produtores em desenvolvimento na América Latina, a nova crise cafeeira que se delineia trouxe o impulso decisivo para o começo dos anos 1960 segundo um empenho vagaroso em relação ao acordo internacional para o ajuste da produção e consumo de café.

239 Segundo IBGE, Censo Agrícola de 1960. Santa Catarina - Paraná.

240 O conceito de formação econômica foi cunhado pela primeira vez por Waibel em 1927, no exemplo de Sierra Madre de Chiapas. Pfeifer (1936) o introduziu posteriormente como formação agrícola. Para apresentação sistemática das observações de formação agrícola, cf. Nitz (1970, p. 82), assim como declarações na ocasião do simpósio sobre Waibel em Pfeifer (1972). 